DOI: $10.5800 /$ GT-2020-11-1-0465

\title{
AGE OF THE EARLY PALEOZOIC GRANITOID MAGMATISM IN THE CENTRAL PART OF THE BUREYA CONTINENTAL MASSIF, CENTRAL ASIAN FOLD BELT
}

\section{R.O. Ovchinnikov ${ }^{1}$, A.A. Sorokin ${ }^{1}$, N.M. Kudryashov' ${ }^{2}$, V.P. Kovach ${ }^{3}$, J.V. Plotkina ${ }^{3}$, T.M. Skovitina ${ }^{4}$}

${ }^{1}$ Institute of Geology and Nature Management, Far East Branch of RAS, Blagoveshchensk, Russia

${ }^{2}$ Institute of Geology, Kola Scientific Centre of RAS, Apatity, Russia

${ }^{3}$ Institute of Precambrian Geology and Geochronology RAS, St. Petersburg, Russia

${ }^{4}$ Institute of the Earth's Crust, Siberian Branch of RAS, Irkutsk, Russia

ABSTRACT. The article presents new age data on the 'key' Early Paleozoic igneous complexes located in the central part of the Bureya continental massif of the Central Asian Fold Belt. Porphyroblastic quartz monzonites of the Kivili complex are dated to $453 \pm 2 \mathrm{Ma}$. The age of gneissic granites of the Sularin complex is $\sim 481 \mathrm{Ma}$. The Sm-Nd isotope studies show that Late Ordovician quartz monzonites were formed mainly from crustal sources with Paleoproterozoic Nd model isotopic ages. Both ancient (Paleoproterozoic?) and younger sources were involved in the formation of Cambrian granites. Our data, as well as previously published materials, suggest several stages of the Early Paleozoic magmatism in the evolution of the Bureya continental massif: 541, 504-500, 487, 474 and 453 Ma. Early Paleozoic magmatism developed under a similar scenario in the Jiamusi continental massif. In addition to the synchronism of Neoproterozoic magmatism within these continental massifs, this feature testifies to their common geological history.

KEYWORDS: Bureya continental massif; Central Asian Fold Belt; granitoid magmatism; U-Pb and U-Th-Pb geochronology; Early Paleozoic; source

FUNDING: The geological studies were carried out according to the scientific research programme of the Institute of Geology and Nature Management FEB RAS. The geochemical, isotope-geochemical and geochronological studies were supported by RFBR (grant 19-05-00103). 


\title{
ВОЗРАСТНЫЕ РУБЕЖИ ПРОЯВЛЕНИЯ РАННЕПАЛЕОЗОЙСКОГО ГРАНИТОИДНОГО МАГМАТИЗМА ЦЕНТРАЛЬНОЙ ЧАСТИ БУРЕИНСКОГО КОНТИНЕНТАЛЬНОГО МАССИВА ЦЕНТРАЛЬНО-АЗИАТСКОГО СКЛАДЧАТОГО ПОЯСА
}

\author{
Р.О. Овчинников ${ }^{1}$, А.А. Сорокин ${ }^{1}$, Н.М. Кудряшов ${ }^{2}$, В.П. Ковач ${ }^{3}$, Ю.В. Плоткина ${ }^{3}$, Т.М. Сковитина ${ }^{4}$
}

\author{
${ }^{1}$ Институт геологии и природопользования Дальневосточного отделения РАН, Благовещенск, Россия \\ ${ }^{2}$ Геологический институт Кольского научного центра РАН, Апатиты, Россия \\ ${ }^{3}$ Институт геологии и геохронологии докембрия РАН, Санкт-Петербург, Россия \\ ${ }^{4}$ Институт земной коры Сибирского отделения РАН, Иркутск, Россия
}

\begin{abstract}
АНнОТАЦИЯ. Представлены новые данные о возрасте «ключевых» раннепалеозойских магматических комплексов центральной части Буреинского континентального массива Центрально-Азиатского складчатого пояса. Показано, что возраст порфиробластических кварцевых монцонитов кивилийского комплекса составляет $453 \pm 2$ млн лет, а гнейсовидных гранитов суларинского комплекса - около 481 млн лет. Результаты Sm-Nd изотопных исследований свидетельствуют о том, что позднеордовикские кварцевые монцониты образовались преимущественно за счет коровых источников, обладающих палеопротерозойскими $\mathrm{Nd}$ модельными изотопными возрастами. В формировании кембрийских гранитов принимали участие как древний (палеопротерозойский?), так и более молодой источник. Полученные данные, а также опубликованные ранее материалы указывают на проявление нескольких этапов раннепалеозойского магматизма в истории формирования Буреинского континентального массива, а именно 541, 504-500, 487, 474, 453 млн лет. По близкому сценарию развивался раннепалеозойский магматизм и в пределах Цзямусинского континентального массива. Наряду с синхронностью проявления неопротерозойского магматизма в пределах указанных континентальных массивов данное обстоятельство свидетельствует о их общей геологической истории.
\end{abstract}

КЛЮЧЕВЫЕ СЛОВА: Буреинский континентальный массив; Центрально-Азиатский складчатый пояс; гранитоидный магматизм; U-Pb и U-Th-Pb геохронология; ранний палеозой; источники

ФИНАНСИРОВАНИЕ: Геологические исследования выполнены в соответствии с планом НИР ИГиП ДВО РАН, геохимические, изотопно-геохимические и геохронологические исследования - при поддержке Российского фонда фундаментальных исследований (грант № 19-05-00103).

\section{1. ВВЕДЕНИЕ}

Центрально-Азиатский складчатый пояс является одной из главнейших тектонических структур Евразии. Его чрезвычайно сложное строение определяется сочетанием многочисленных континентальных массивов и разделяющих их более мелких разновозрастных складчатых поясов, расположенных между СевероАзиатским, Сино-Корейским и Таримским кратонами [Mossakovsky et al., 1993; Şengör, Natal'in, 1996; Jahn, 2004; Yarmoluk et al., 2012; Zhou, Wilde, 2013; Kröner, 2015; Zhou et al., 2018; и дp.]. В восточной части пояса наиболее крупными континентальными массивами (террейнами) являются Аргунский, Буреинский (Туранский), Малохинганский (Цзямусинский) и Ханкайский. При этом три последних обычно рассматриваются в качестве составных частей Буреинско-Цзямусинского супертеррейна [Khanchuk, 2000, 2006; Parfenov et al., 2003] (рис. 1). Происхождение этих континентальных массивов является одним из кардинальных вопросов геодинамической эволюции Центрально-Азиатского складчатого пояса. Согласно одному сценарию, они представляют собой фрагменты суперконтинента Гондвана [Mossakovsky et al., 1993; Khanchuk, 2000; Zhou et al., 2018; u ссылки в этих работах]. Альтернативная модель предполагает обособление указанных террейнов от южной окраины Сибирского континента, их последовательное продвижение вдоль этой окраины с запада на восток и последующую аккрецию в результате косой субдукции [Sengör, Natal'in, 1996; Parfenov et al., 2003; и ссылки в этих работах].

Наиболее важное значение для решения указанной проблемы имеет получение достоверной информации о последовательности, возрасте и геодинамических обстановках проявления магматических и метаморфических процессов в истории формирования Буреинско-Цзямусинского супертеррейна. При этом ключевое значение имеет изучение именно позднедокембрийских и раннепалеозойских комплексов [Mossakovsky et al., 1993; Didenko et al., 1994; Parfenov et al., 2003; и дp.]. В этой связи были проведены комплексные геологические, геохимические, геохронологические и изотопно-геохимические исследования раннепалеозойских магматических образований центральной части Буреинского континентального массива.

\section{2. ОСНОВНЫЕ ЧЕРТЫ ГЕОЛОГИЧЕСКОГО СТРОЕНИЯ БУРЕИНСКОГО КОНТИНЕНТАЛЬНОГО МАССИВА И ОБЪЕКТЫ ИССЛЕДОВАНИЙ}

По существующим ныне представлениям, отраженным в легендах геологических карт последнего поколения [Petruk, Volkova, 2006; Zabrodin et al., 2007; Serezhnikov, Volkova, 2007; Vas'kin, Dymovich, 2009], к 
наиболее древним образованиям Буреинского континентального массива относятся архейские метаморфические комплексы, Р-Т условия формирования которых соответствуют амфиболитовой фации. Так же, как и в соседнем Цзямусинском континентальном массиве, первоначально они рассматривались в составе амурской серии [Zubkov, Turbin, 1984; Vas'kin, 1984; Zubkov, Vas'kin, 1984; u dp.]. Позднее раннедокембрийские образования Буреинского континентального массива стали относить к дягдаглейской толще, а амурскую серию выделять только в пределах Цзямусинского континентального массива [Resolutions..., 1994].

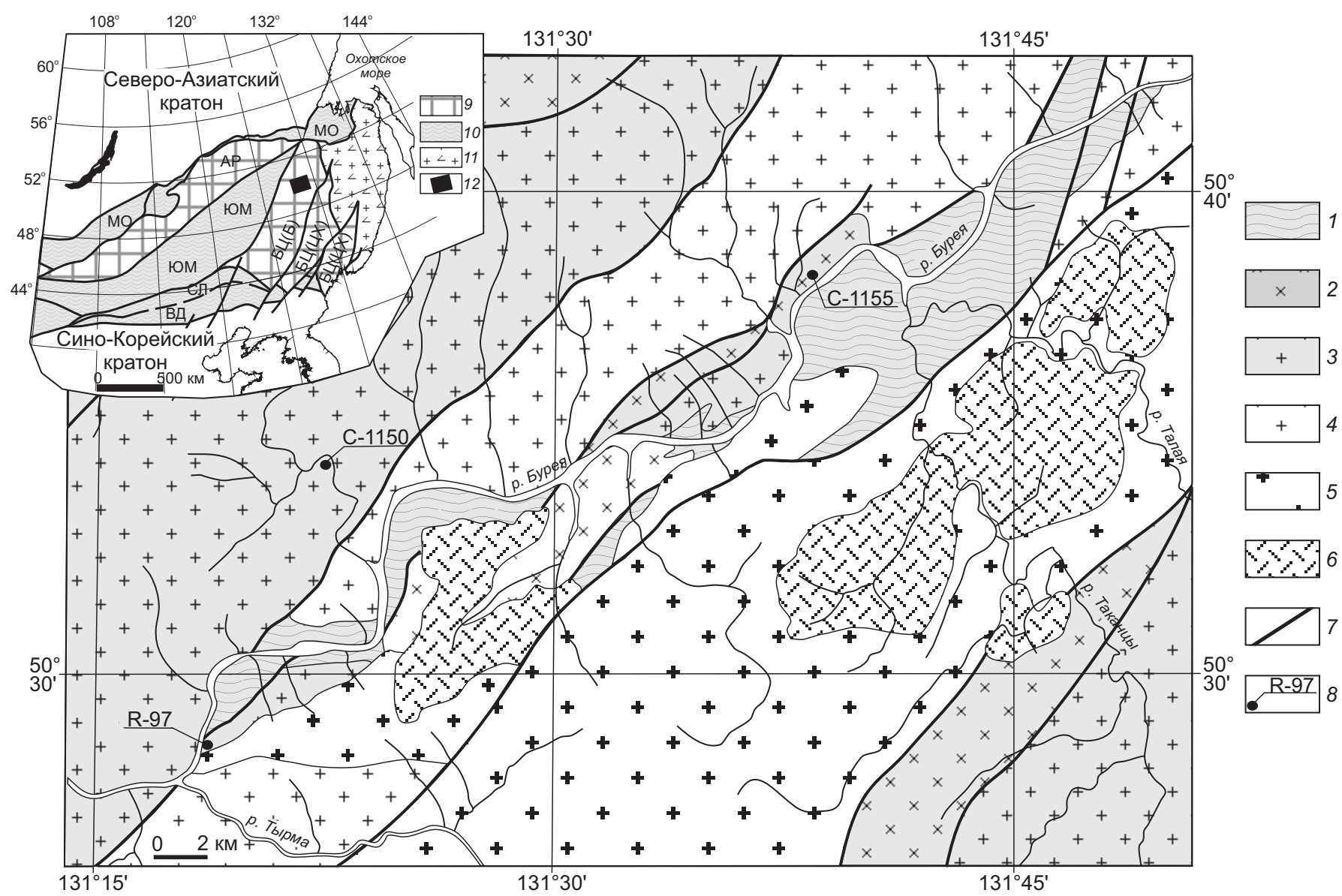

Рис. 1. Геологическая схема северной части Буреинского континентального массива и детальных участков (в верхнем течении р. Бурея).

Составлена по [Vasil'eva, 1960; Vas'kin, 1984] с изменениями авторов. 1 - нерасчлененные метаморфические комплексы условно архейского и палеопротерозойского возраста; 2 - условно раннепалеозойские гранитоиды кивилийского комплекса; 3 - условно раннепалеозойские гранитоиды суларинского комплекса; 4 - условно позднепалеозойские гранитоиды тырмо-буреинского комплекса; 5 - раннемезозойские гранитоиды алтахтинского и харинского комплексов; 6 - раннемезозойские кислые вулканические породы таловского комплекса; 7 - главные разломы; 8 - места отбора образцов для геохронологических исследований и их номера. На врезке показано положение исследуемых объектов в структуре восточной части ЦентральноАзиатского складчатого пояса (тектоническая основа по [Parfenov et al., 2003]) с изменениями авторов): 9 - супертеррейны: $\mathrm{AP}$ - Аргунский, БЦ - Буреинско-Цзямусинский (БЦ(Б) - Буреинский террейн (континентальный массив), БЦ(ЦХ) - ЦзямусиХанкайский террейн (континентальный массив)); 10 - палеозойские-раннемезозойские складчатые пояса (МО - МонголоОхотский, ЮМ - Южномонгольский, СЛ - Солонкерский, ВД - Вундурмиао); 11 - позднеюрско-раннемеловые орогенные пояса; 12 - район исследования.

Fig. 1. Geological map of the northern part of the Bureya continental massif and detailed sections (in the upper reaches of the Bureya river).

Modified after [Vasil'eva, 1960; Vas'kin, 1984]. 1 - undivided Archean(?) and Paleoproterozoic(?) metamorphic complexes; 2 - conditionally Early Paleozoic granitoids of the Kivili complex; 3 - conditionally Early Paleozoic granitoids of the Sularin complex; 4 - conditionally Late Paleozoic granitoids of the Tyrmo-Bureya complex; 5 - Early Mesozoic granitoids of the Altakhta and Kharin complexes; 6 - Early Mesozoic felsic volcanic rocks of the Talovka complex; 7 - major faults; 8 - locations of samples for geochronological studies and sample numbers. Inset: Location of the studied objects in the eastern part of the Central Asian Fold Belt (modified after [Parfenov et al., 2003]): 9 - superterranes: AP - Argun, БЦ - Bureya-Jiamusi (БЦ(Б) - Bureya terrane (continental massif), БЦ(ЦХ) - JiamusiKhanka terrane (continental massif)); 10 - Paleozoic - Early Mesozoic fold belts (MO - Mongol-Okhotsk, ЮM - South Mongolian, СЛ Solonker , ВД - Wundurmiao); 11 - Late Jurassic - Early Cretaceous orogenic belts; 12 - study area. 
С метаморфическими образованиями дягдаглейской толщи пространственно ассоциируют тела метаморфизованных габброидов амурского и гранитоидов древнебуреинского комплекса, также отнесенных к архею [Petruk, Volkova, 2006; Zabrodin et al., 2007; Serezhnikov, Volkova, 2007; Vas'kin, Dymovich, 2009]. Однако оказалось, что габбро-амфиболиты амурского комплекса

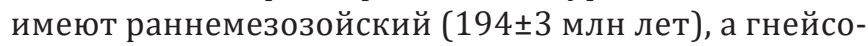
видные биотитовые лейкограниты древнебуреинско-

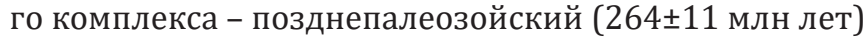
возраст [Ovchinnikov et al., 2018].

К палеопротерозойским образованиям Буреинского континентального массива в современных схемах расчленения и корреляции геологических комплексов отнесены слюдистые, часто углеродистые сланцы с пластами кварцитов и мраморов нятыгранской свиты, а также интрузии габброидов и гранитоидов нятыгранского комплекса [Petruk, Volkova, 2006; Khanchuk, 2006; Martynyuk et al., 1990]. В то же время недавно полученные геохронологические данные указывают на то, что в состав нятыгранского комплекса включены интрузии двух этапов неопротерозойского магматизма - 940933 и 804-789 млн лет [Sorokin et al., 2017].

К неопротерозою (верхнему рифею в стратиграфической шкале России) отнесены терригенные, терригенно-карбонатные и вулканогенные отложения туранской серии [Serezhnikov, Volkova, 2007; Vas'kin, Dymovich, 2009; Resolutions..., 1994]. Данные, подтверждающие их неопротерозойский возраст, отсутствуют. Напротив, для метариолитов и метапесчаников туранской серии установлен раннепалеозойский возраст [Sorokin et al., 2011b, 2014]. Вендские (в стратиграфической шкале России) и нижнекембрийские терригенно-карбонатные отложения, содержащие микрофитолиты и археоциаты (мельгинская, чергиленская, аллинская свиты), представлены в центральной части Буреинского континентального массива в пределах Мельгинского прогиба [Resolutions..., 1994; Petruk, Volkova, 2006; Khanchuk, 2006].

Большая часть Буреинского континентального массива сложена ранне- и позднепалеозойскими, а также раннемезозойскими гранитоидами. При этом критерии отнесения этих гранитоидов к тому или иному комплексу, а также их возраст остаются предметом дискуссий (см. обзоры в [Martynyuk et al., 1990; Khanchuk, 2006; Sorokin et al., 2007, 2011a, 2016]). Наиболее ранние из них представлены габброгранитовым кивилийским и гранитовым суларинским комплексами [Petruk, Volkova, 2006; Zabrodin et al., 2007; Serezhnikov, Volkova, 2007; Vas'kin, Dymovich, 2009]. В легендах геологических карт последнего поколения эти образования считаются ордовикскими [Petruk, Volkova, 2006; Zabrodin et al., 2007; Serezhnikov, Volkova, 2007; Vas'kin, Dymovich, 2009], хотя приводимые для них немногочисленные геохронологические данные варьируются в широких пределах, что дает повод для дискуссий о их возрасте.

Наиболее распространены в пределах Буреинского континентального массива известково-щелочные гранитоиды, относимые [Martynyuk et al., 1990; Petruk, Volkova, 2006; Vas'kin, Dymovich, 2009; и дp.] к позднепалеозойскому многофазному габбро-диорит-гранодиорит-гранитному тырмо-буреинскому комплексу. Однако установлено, что целая серия петротипических массивов этого комплекса имеет не позднепалеозойский, а раннемезозойский возраст - 218-185 млн лет [Sorokin et al., 2007, 2010a]. В этом же возрастном интервале находятся оценки возраста, полученные для щелочных и субщелочных гранитоидов алтахтинского и харинского комплексов, а также вулканитов таловского комплекса [Sorokin et al., 2016].

Таким образом, Буреинский континентальный массив имеет весьма сложное строение, при этом для большинства геологических комплексов отсутствуют надежные данные о возрасте. Это обстоятельство делает практически невозможным корректную реконструкцию истории его формирования.

Как было отмечено выше, объектами наших исследований являются раннепалеозойские магматические образования центральной части Буреинского континентального массива в бассейне р. Бурея: порфиробластические кварцевые монцониты кивилийского комплекса массива Самыкинский и гнейсовидные граниты УстьТырминского массива суларинского комплекса (см. рис. 1). Выбор этих объектов обусловлен следующими обстоятельствами. Во-первых, ранее были получены данные о том, что возраст порфиробластических роговообманково-биотитовых гранитов Кивилийского массива одноименного комплекса составляет $474 \pm 1$ млн лет [Sorokin et al., 2011a], а гнейсовидных гранитов Сула-

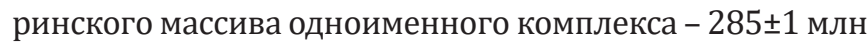
лет [Sorokin, Kudryashov, 2012]. Однако эти единичные оценки возраста не позволяют с какой-либо определенностью говорить об этапах проявления раннепалеозойского интрузивного магматизма, что потребовало проведения дополнительных исследований.

Самыкинский массив $(1.5 \times 5.0$ км) кивилийского комплекса расположен на правобережье реки Бурея в приустьевой части одноименного ручья (см. рис. 1). Он сложен порфиробластическими биотит-роговообманковыми кварцевыми монцонитами и биотитовыми гранитами. Его контакты с позднепалеозойскими гранитоидами тырмо-буреинского комплекса имеют как тектонический, так и интрузивный характер.

Усть-Тырминский массив $(1 \times 6$ км) суларинского комплекса находится на левобережье реки Бурея в приустьевой части реки Тырма (см. рис. 1). Массив сложен преимущественно амфибол-биотитовыми, реже биотитовыми гнейсовидными гранитами. С северо-запада они имеют тектонический контакт с метаморфическими образованиями, относимыми к архею, а в юго-восточной части массива прорваны позднепалеозойскими гранитоидами тырмо-буреинского комплекса.

\section{3. АНАЛИТИЧЕСКИЕ МЕТОДИКИ}

Определение содержаний породообразующих элементов и Zr в породах выполнено рентгенофлуоресцентным методом на рентгеновском спектрометре 
Pioneer $4 \mathrm{~S}$ в Институте геологии и природопользования ДВО РАН (г. Благовещенск), а микроэлементов - методом ICP-MS на масс-спектрометре Elan 6100 DRC в Институте тектоники и геофизики ДВО РАН (г. Хабаровск). Подробное описание вышеуказанных методов приведено в статье [Sorokin et al., 2017].

$\mathrm{Sm}-\mathrm{Nd}$ изотопные исследования выполнены в Институте геологии и геохронологии докембрия РАН (г. СанктПетербург). Подробное описание методики исследований приведено в статье [Sorokin et al., 2019].

$\mathrm{U}-\mathrm{Pb}$ геохронологические исследования (ID-TIMS) циркона из биотит-роговообманкового порфиробластического кварцевого монцонита кивилийского комплекса выполнены в Геологическом институте КНЦ РАН (г. Апатиты). Выделение циркона проводилось по стандартной методике с использованием тяжелых жидкостей и магнитной сепарации. Выбранные для $\mathrm{U}-\mathrm{Pb}$ геохронологических исследований кристаллы циркона подвергались многоступенчатому удалению поверхностных загрязнений в спирте, ацетоне и $1 \mathrm{M}$ $\mathrm{HNO}_{3}$. Описание методики исследований приведено в работе [Sorokin et al., 2017].

Выделение циркона для U-Th-Pb геохронологических исследований (LA-ICP-MS) выполнено в минералогической лаборатории Института геологии и природопользования ДВО РАН с помощью тяжелых жидкостей. Выделенные цирконы совместно со стандартными цирконами (FC, SL и R33) были вмонтированы в шашку, изготовленную из эпоксидной смолы, и приполированы приблизительно до середины зерен. Строение зерен циркона изучалось в режиме BSE на сканирующем электронном микроскопе Hitachi S-3400N, оснащенном детектором Gatan Chroma CL2.
U-Th-Pb геохронологические исследования (LA-ICPMS) циркона проведены в Геохронологическом центре Аризонского университета (Arizona LaserChron Center, USA) (детали аналитической методики изложены на сайте www.laserchron.org).

\section{4. ПЕТРОГРАФИЧЕСКИЕ И ГЕОХИМИЧЕСКИЕ ОСОБЕННОСТИ ГРАНИТОИДОВ}

\section{1. Биотит-роговообманковые}

\section{порфиробластические кварцевые монцониты}

\section{кивилийского комплекса}

Данные породы сложены плагиоклазом (41-46 \%), калиевым полевым шпатом (19-25 \%), кварцем (12$15 \%)$, амфиболом (12-15\%) и биотитом (7-15\%) (рис. 2, a). Акцессорные минералы представлены цирконом, сфеном, апатитом, ильменитом, пиритом, шеелитом, цоизитом. Структура кварцевых монцонитов порфиробластическая. Порфиробласты размером от 1-4 см до 6 см представлены в основном микроклинпертитом. Текстура кварцевых монцонитов гнейсовидная.

По соотношению $\mathrm{SiO}_{2}(62.32-64.80$ \%) и суммы щелочей $\mathrm{K}_{2} \mathrm{O}+\mathrm{Na}_{2} \mathrm{O}$ (7.09-8.23\%) (табл. 1, рис. 3) порфиробластические кварцевые монцониты соответствуют умеренно щелочным породам. Они характеризуются высокими значениями отношения $\mathrm{FeO}^{*} / \mathrm{MgO}$ (8.73-9.12), а также умеренными величинами ASI= 0.89-0.94, свойственными метаглиноземистым породам (рис. 4).

Распределение REE в порфиробластических биотит-роговообманковых кварцевых монцонитах имеет умеренно дифференцированный характер ([La/Yb]n= 5.17-8.62) при отчетливо выраженной отрицательной европиевой аномалии (Eu/Eu*=0.36-0.47) (см. рис. 5, $a$ ).
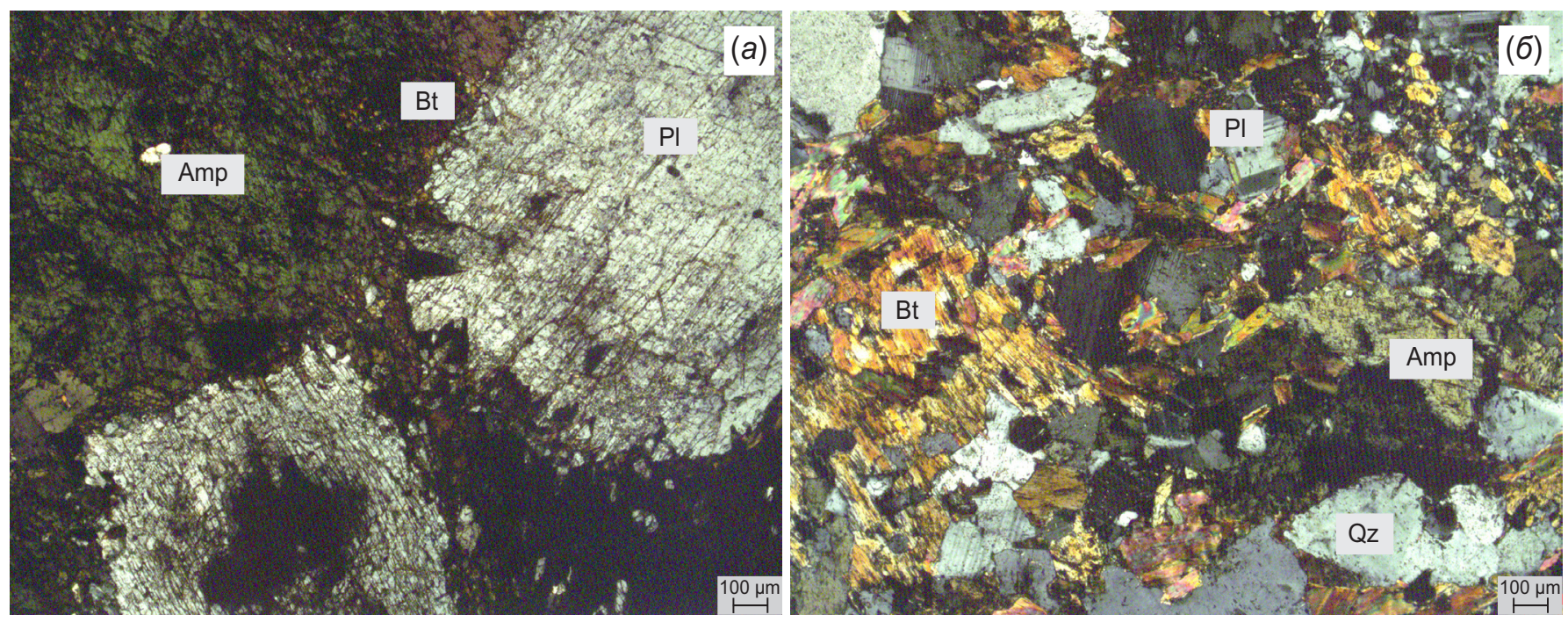

Рис. 2. Микрофотографии шлифов биотит-роговообманкового порфиробластического кварцевого монцонита (обр. C-1155) кивилийского комплекса (a) и амфибол-биотитового гнейсовидного гранита (обр. R-97) суларинского комплекса (б).

Amp - амфибол; Bt - биотит; Pl - плагиоклаз; Qz - кварц.

Fig. 2. Photomicrographs (cross-polarized light) of biotite-hornblende porphyroblastic quartz monzonite (sample C-1155) of the Kivili complex (a) and amphibole-biotite gneiss-granite (sample R-97) of the Sularin complex (б).

Amp - amphibole; Bt - biotite; $\mathrm{Pl}$ - plagioclase; $\mathrm{Qz}$ - quartz. 
Таблица 1. Химический состав представительных образцов раннепалеозойских магматических пород Буреинского континентального массива

Table 1. Chemical composition of representative samples of the Early Paleozoic igneous rocks of the Bureya continental massif

\begin{tabular}{|c|c|c|c|c|c|c|c|c|}
\hline \multirow{2}{*}{$\begin{array}{l}\text { Образец/ } \\
\text { компоненты }\end{array}$} & c-1155 & c-1155-1 & $c-1155-2$ & c-1155-3 & c-1155-4 & R97-1 & R97-2 & R97-3 \\
\hline & 1 & 2 & 3 & 4 & 5 & 6 & 7 & 8 \\
\hline $\mathrm{SiO}_{2}$ & 63.90 & 63.51 & 64.80 & 62.32 & 63.79 & 70.66 & 70.14 & 70.21 \\
\hline $\mathrm{TiO}_{2}$ & 1.00 & 1.00 & 0.91 & 1.14 & 0.97 & 0.34 & 0.41 & 0.33 \\
\hline $\mathrm{Al}_{2} \mathrm{O}_{3}$ & 14.19 & 14.28 & 14.08 & 14.00 & 14.12 & 14.82 & 14.21 & 15.04 \\
\hline $\mathrm{Fe}_{2} \mathrm{O}_{3}{ }^{*}$ & 8.37 & 8.43 & 7.53 & 9.75 & 8.16 & 3.32 & 3.66 & 3.41 \\
\hline $\mathrm{MnO}$ & 0.12 & 0.12 & 0.15 & 0.14 & 0.12 & 0.07 & 0.07 & 0.07 \\
\hline $\mathrm{MgO}$ & 0.84 & 0.87 & 0.75 & 1.00 & 0.81 & 0.68 & 0.81 & 0.62 \\
\hline $\mathrm{CaO}$ & 2.82 & 3.08 & 2.73 & 3.42 & 2.94 & 2.26 & 2.78 & 2.34 \\
\hline $\mathrm{Na}_{2} \mathrm{O}$ & 2.87 & 3.10 & 3.14 & 3.00 & 3.04 & 3.50 & 3.75 & 4.04 \\
\hline $\mathrm{K}_{2} \mathrm{O}$ & 4.89 & 4.58 & 5.09 & 4.09 & 5.10 & 3.53 & 3.18 & 3.47 \\
\hline $\mathrm{P}_{2} \mathrm{O}_{5}$ & 0.28 & 0.27 & 0.24 & 0.30 & 0.25 & 0.10 & 0.13 & 0.08 \\
\hline ппп & 0.66 & 0.69 & 0.59 & 0.81 & 0.50 & 0.26 & 0.42 & 0.41 \\
\hline Сумм & 99.92 & 99.94 & 100.00 & 99.98 & 99.79 & 99.54 & 99.56 & 100.02 \\
\hline $\mathrm{Ga}$ & 25.00 & 25.00 & 24.00 & 25.00 & 24.00 & 20.00 & 19.00 & 20.00 \\
\hline $\mathrm{Rb}$ & 185.00 & 179.00 & 195.00 & 150.00 & 180.00 & 178.00 & 160.00 & 159.00 \\
\hline $\mathrm{Sr}$ & 146.00 & 149.00 & 151.00 & 135.00 & 141.00 & 194.00 & 376.00 & 180.00 \\
\hline $\mathrm{Ba}$ & 1430.00 & 1306.00 & 1483.00 & 1136.00 & 1412.00 & 1080.00 & 1520.00 & 953.00 \\
\hline $\mathrm{La}$ & 57.80 & 64.80 & 52.00 & 51.30 & 72.90 & 39.20 & 18.40 & 22.30 \\
\hline $\mathrm{Ce}$ & 129.20 & 136.00 & 119.20 & 137.40 & 145.90 & 65.70 & 46.50 & 44.30 \\
\hline $\operatorname{Pr}$ & 14.04 & 15.00 & 12.93 & 14.82 & 15.49 & 8.32 & 4.89 & 5.11 \\
\hline $\mathrm{Nd}$ & 63.24 & 66.89 & 57.78 & 69.59 & 68.14 & 30.90 & 19.50 & 19.90 \\
\hline $\mathrm{Sm}$ & 13.15 & 13.57 & 11.97 & 15.05 & 13.66 & 5.69 & 4.56 & 4.73 \\
\hline $\mathrm{Eu}$ & 2.06 & 2.03 & 1.97 & 1.91 & 2.07 & 0.98 & 1.45 & 0.91 \\
\hline Gd & 14.94 & 15.05 & 13.54 & 16.93 & 15.32 & 5.13 & 4.51 & 5.20 \\
\hline $\mathrm{Tb}$ & 1.87 & 1.91 & 1.71 & 2.16 & 1.90 & 0.80 & 0.74 & 0.96 \\
\hline Dy & 11.22 & 11.43 & 10.33 & 13.20 & 11.59 & 4.78 & 4.45 & 6.21 \\
\hline Но & 2.04 & 2.07 & 1.86 & 2.42 & 2.10 & 1.00 & 0.88 & 1.33 \\
\hline Er & 6.31 & 6.58 & 5.84 & 7.58 & 6.54 & 3.05 & 2.53 & 4.17 \\
\hline $\mathrm{Tm}$ & 0.79 & 0.81 & 0.73 & 0.95 & 0.81 & 0.47 & 0.39 & 0.66 \\
\hline $\mathrm{Yb}$ & 5.71 & 5.82 & 5.16 & 6.74 & 5.74 & 3.25 & 2.60 & 4.57 \\
\hline $\mathrm{Lu}$ & 0.79 & 0.80 & 0.71 & 0.92 & 0.79 & 0.49 & 0.39 & 0.68 \\
\hline Y & 53.00 & 53.00 & 48.00 & 61.00 & 53.00 & 30.00 & 25.00 & 41.00 \\
\hline $\mathrm{Nb}$ & 25.00 & 25.00 & 22.00 & 27.00 & 24.00 & 13.00 & 11.00 & 13.00 \\
\hline $\mathrm{Ta}$ & 1.49 & 1.45 & 1.29 & 1.58 & 1.37 & 1.19 & 0.71 & 1.61 \\
\hline $\mathrm{Hf}$ & 1.47 & 1.51 & 1.28 & 1.68 & 1.41 & 5.08 & 5.72 & 5.11 \\
\hline $\mathrm{Zr}$ & 356.00 & 358.00 & 345.00 & 342.00 & 354.00 & 179.00 & 188.00 & 175.00 \\
\hline Th & 17.97 & 15.72 & 11.61 & 15.47 & 14.06 & 10.90 & 9.47 & 12.70 \\
\hline $\mathrm{U}$ & 2.57 & 3.06 & 2.22 & 2.65 & 3.39 & 4.86 & 2.57 & 6.40 \\
\hline $\mathrm{Pb}$ & 37.00 & 34.00 & 46.00 & 34.00 & 35.00 & 31.00 & 26.00 & 27.00 \\
\hline $\mathrm{Cu}$ & 14.00 & 22.00 & 13.00 & 17.00 & 15.00 & 58.00 & 61.00 & 39.00 \\
\hline $\mathrm{Zn}$ & 160.00 & 162.00 & 169.00 & 181.00 & 144.00 & 104.00 & 85.00 & 79.00 \\
\hline Sc & 14.00 & 14.00 & 13.00 & 16.00 & 14.00 & 7.00 & 9.00 & 7.00 \\
\hline V & 25.00 & 28.00 & 24.00 & 30.00 & 26.00 & 20.00 & 27.00 & 19.00 \\
\hline $\mathrm{Cr}$ & 57.00 & 65.00 & 54.00 & 46.00 & 46.00 & 63.00 & 101.00 & 109.00 \\
\hline Co & 8.00 & 8.00 & 7.00 & 9.00 & 8.00 & 5.00 & 6.00 & 4.00 \\
\hline $\mathrm{Ni}$ & 4.00 & 4.00 & 4.00 & 4.00 & 4.00 & 6.00 & 6.00 & 6.00 \\
\hline
\end{tabular}

Примечание. 1-5 - биотит-роговообманковые порфиробластические кварцевые монцониты кивилийского комплекса, 6-8 - амфиболбиотитовые гнейсовидные граниты суларинского комплекса; содержания главных элементов приведены в мас. \%, малых элементов в мкг $/$ г. $\mathrm{Fe}_{2} \mathrm{O}_{3}{ }^{*}$ - общее железо в форме $\mathrm{Fe}_{2} \mathrm{O}_{3}$.

Note. 1-5 - biotite-hornblende porphyroblastic quartz monzonites of the Kivili complex; 6-8 -amphibole-biotite gneissic granites of the Sularin complex. Major elements in wt\%; trace elements in $\mu \mathrm{g} / \mathrm{g}$. $\mathrm{Fe}_{2} \mathrm{O}_{3}{ }^{*}-$ total iron in the form of $\mathrm{Fe}_{2} \mathrm{O}_{3}$. 


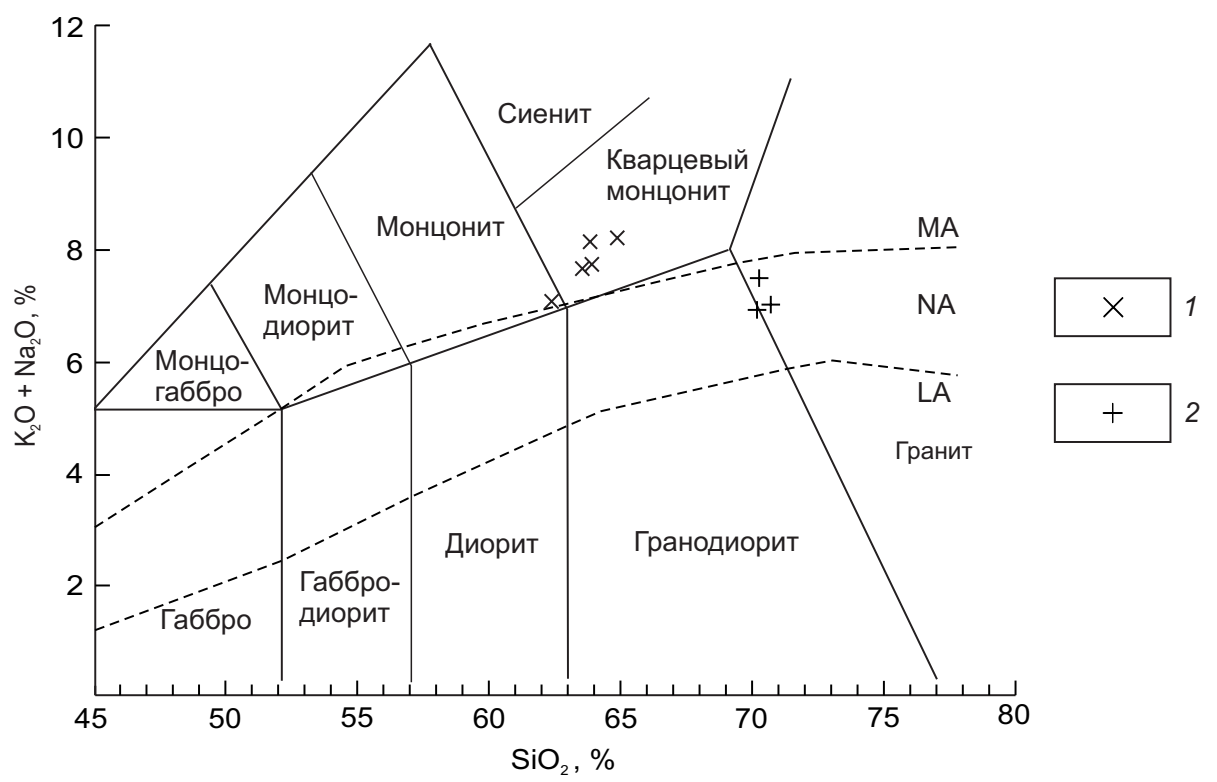

Рис. 3. Классификационная диаграмма $\mathrm{K}_{2} \mathrm{O}+\mathrm{Na}_{2} \mathrm{O}-\mathrm{SiO}_{2}$ [Le Maitre et al., 2002] для раннепалеозойских магматических пород Буреинского континентального массива.

1 - биотит-роговообманковые порфиробластические кварцевые монцониты кивилийского комплекса; 2 - амфиболбиотитовые гнейсовидные граниты суларинского комплекса. Пунктирными линиями показаны границы низко щелочных (LA), нормально-щелочных (NA) и умеренно-щелочных (MA) пород по [Sharpenok et al., 2013a, 2013b].

Fig. 3. $\mathrm{K}_{2} \mathrm{O}+\mathrm{Na}_{2} \mathrm{O}-\mathrm{SiO}_{2}$ classification diagram [Le Maitre et al., 2002] for the Early Paleozoic igneous rocks of the Bureya continental massif.

1 - biotite-hornblende porphyroblastic quartz monzonite of the Kivili complex; 2 - amphibole-biotite gneiss-granite of the Sularin complex. Dashed lines mark the boundaries of low-alkalinity (LA), normal-alkalinity (NA) and medium-alkalinity (MA) rocks, after [Sharpenok et al., 2013a, 2013b].

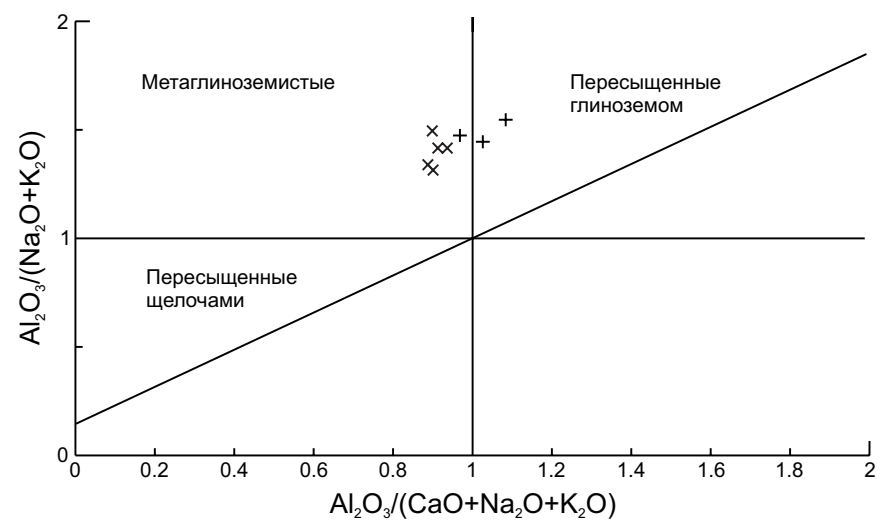

На мультиэлементных диаграммах (рис. 6, a) проявлено относительное обогащение в отношении $\mathrm{Rb}, \mathrm{Ba}$, Th, U, LREE, Pb на фоне дефицита Sr, Ti, в меньшей степени $\mathrm{Nb}$, Та.

\section{2. Амфибол-биотитовые гнейсовидные граниты суларинского комплекса}

Главными породообразующими минералами этих гранитоидов являются кварц (12-35\%), плагиоклаз (23-43\%), калиевый полевой шпат (преимущественно ортоклаз) (9-27\%), биотит (15-25\%) и амфибол (3-11\%) (см. рис. 2, б). Акцессорные минералы представлены цирконом, апатитом, рудными минералами. Структура гранитов суларинского комплекса бластогранитовая, текстура - гнейсовидная.
Рис. 4. Диаграмма $\mathrm{Al}_{2} \mathrm{O}_{3} /\left(\mathrm{Na}_{2} \mathrm{O}+\mathrm{K}_{2} \mathrm{O}\right)-\mathrm{Al}_{2} \mathrm{O}_{3} /\left(\mathrm{CaO}+\mathrm{Na}_{2} \mathrm{O}+\mathrm{K}_{2} \mathrm{O}\right)$ [Maniar, Piccoli, 1989] (молекулярные количества) для раннепалеозойских магматических пород Буреинского континентального массива.

Условные обозначения см. на рис. 3.

Fig. 4. $\mathrm{Al}_{2} \mathrm{O}_{3} /\left(\mathrm{Na}_{2} \mathrm{O}+\mathrm{K}_{2} \mathrm{O}\right)-\mathrm{Al}_{2} \mathrm{O}_{3} /\left(\mathrm{CaO}+\mathrm{Na}_{2} \mathrm{O}+\mathrm{K}_{2} \mathrm{O}\right)$ composition diagram [Maniar, Piccoli, 1989] (molecular quantities) for the Early Paleozoic igneous rocks of the Bureya continental massif. Designations follow Fig. 3.

По соотношению $\mathrm{SiO}_{2}(70.14-70.66 \%)$ и суммы щелочей $\mathrm{K}_{2} \mathrm{O}+\mathrm{Na}_{2} \mathrm{O}$ (6.93-7.51\%) (табл. 1, см. рис. 3) гнейсовидные граниты суларинского комплекса соответствуют породам нормальной щелочности. Для них характерны умеренные значения отношения FeO*/MgO (4.07-4.95), а также значения ASI=0.97-1.08, свойственные пересыщенным глиноземом породам (см. рис. 4).

Распределение REE в амфибол-биотитовых гнейсовидных гранитах имеет слабо и умеренно дифференцированный характер ([La/Yb]n =3.31-8.19) при достаточно хорошо выраженной отрицательной европиевой аномалии (Eu/Eu*=0.54-0.96) (рис. 5, б). Мультиэлементные диаграммы (рис. 6, б) демонстрируют более низкий уровень накопления большинства 
Порода/хондрит

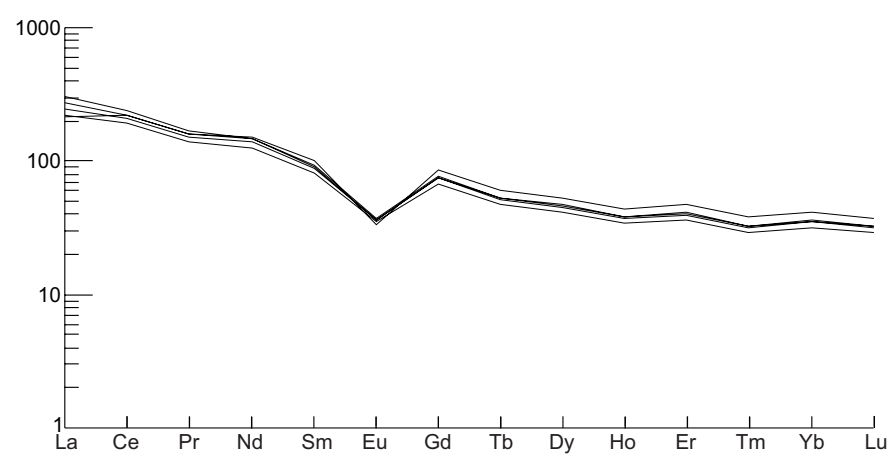

(a) Порода/хондрит

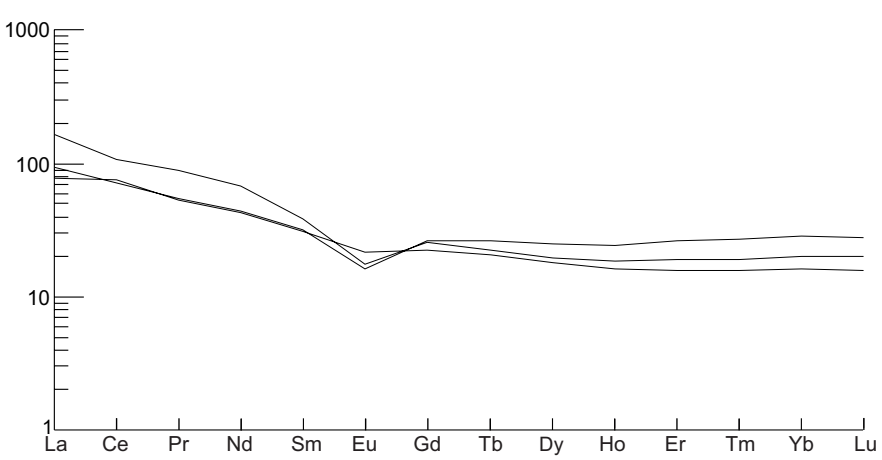

Рис. 5. Распределение редкоземельных элементов в раннепалеозойских биотит-роговообманковых порфиробластических кварцевых монцонитах кивилийского комплекса $(a)$ и амфибол-биотитовых гнейсовидных гранитах суларинского комплекса (б).

Состав хондрита по [McDonough, Sun, 1995].

Fig. 5. Chondrite-normalized [McDonough, Sun, 1995] REE patterns of the biotite-hornblende porphyroblastic quartz monzonite of the Kivili complex (a) and amphibole-biotite gneiss-granite of the Sularin complex (б).

Порода/Примитивная мантия

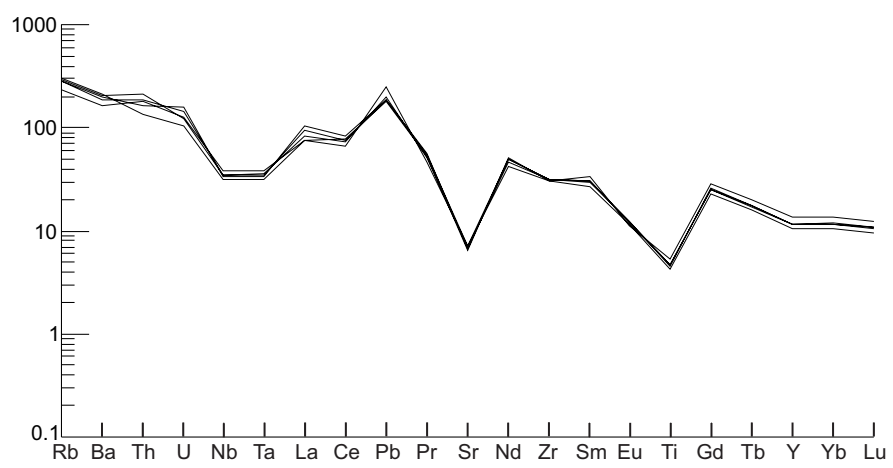

(a) Порода/Примитивная мантия

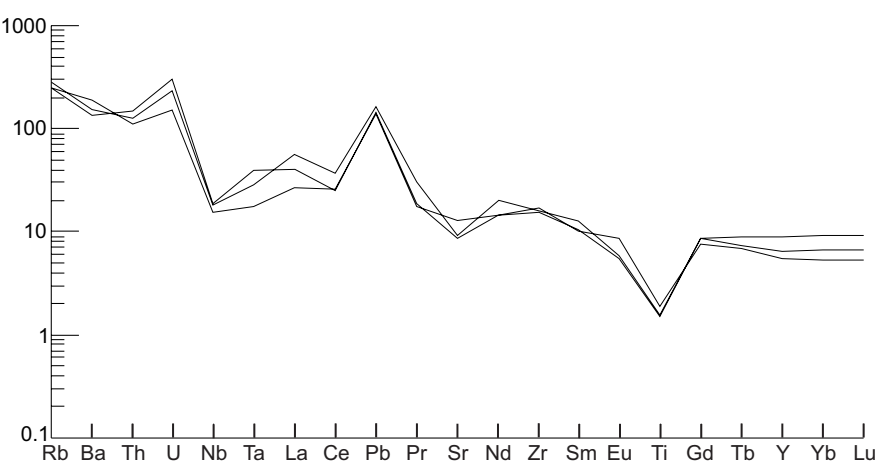

Рис. 6. Распределение редких элементов в раннепалеозойских биотит-роговообманковых порфиробластических кварцевых монцонитах кивилийского комплекса (a) и амфибол-биотитовых гнейсовидных гранитах суларинского комплекса (б). Состав примитивной мантии по [Sun, McDonough, 1989].

Fig. 6. Primitive-mantle-normalized [Sun, McDonough, 1989] trace-element patterns of the biotite-hornblende porphyroblastic quartz monzonite of the Kivili complex $(a)$ and amphibole-biotite gneiss-granite of the Sularin complex (б).

литофильных элементов в гнейсовидных гранитах суларинского комплекса по сравнению с гранитоидами кивилийского комплекса.

\section{5. РЕЗУЛЬТАТЫ U-Pb И U-Th-Pb ГЕОХРОНОЛОГИЧЕСКИХ ИССЛЕДОВАНИЙ 5.1. Биотит-роговообманковый порфиробластический кварцевый монцонит кивилийского комплекса (обр. С-1155)}

Место отбора образца показано на рис. 1. Циркон, выделенный из этого образца, представлен прозрачными идиоморфными и субидиоморфными длиннопризматическими кристаллами (рис. 7, a-2) кремового цвета, основными элементами огранки которых являются грани призмы $\{110\}$ и дипирамиды $\{111\}$. Размер кристаллов циркона изменяется от 500 до 50 мкм $\left(\mathrm{K}_{\text {удл. }}=3.0-4.0\right)$, а их строение характеризуется отчетливо проявленной «тонкой» зональностью (рис. 7, $\partial-3$ ).
Иногда в кристаллах циркона присутствуют включения кварца и апатита.

Для проведения $\mathrm{U}-\mathrm{Pb}$ геохронологических исследований (ID-TIMS) использованы четыре навески кристаллов циркона без видимых включений, отобранные из размерных фракций 500+150 мкм, -150+100 мкм, $-100+70$ мкм и -70+50 мкм (табл. 2). Точки их изотопного состава располагаются на конкордии (рис. 8, a). Для них получена средневзвешенная оценка возраста $453 \pm 2$ млн лет $($ СКВО=1.4, вероятность конкордантности - 0.23).

Морфологические особенности изученного циркона свидетельствуют о его магматическом происхождении, поэтому есть все основания рассматривать полученную для него конкордантную оценку возраста $453 \pm 2$ млн лет как возраст кристаллизации биотитроговообманковых порфиробластических кварцевых монцонитов кивилийского комплекса. 


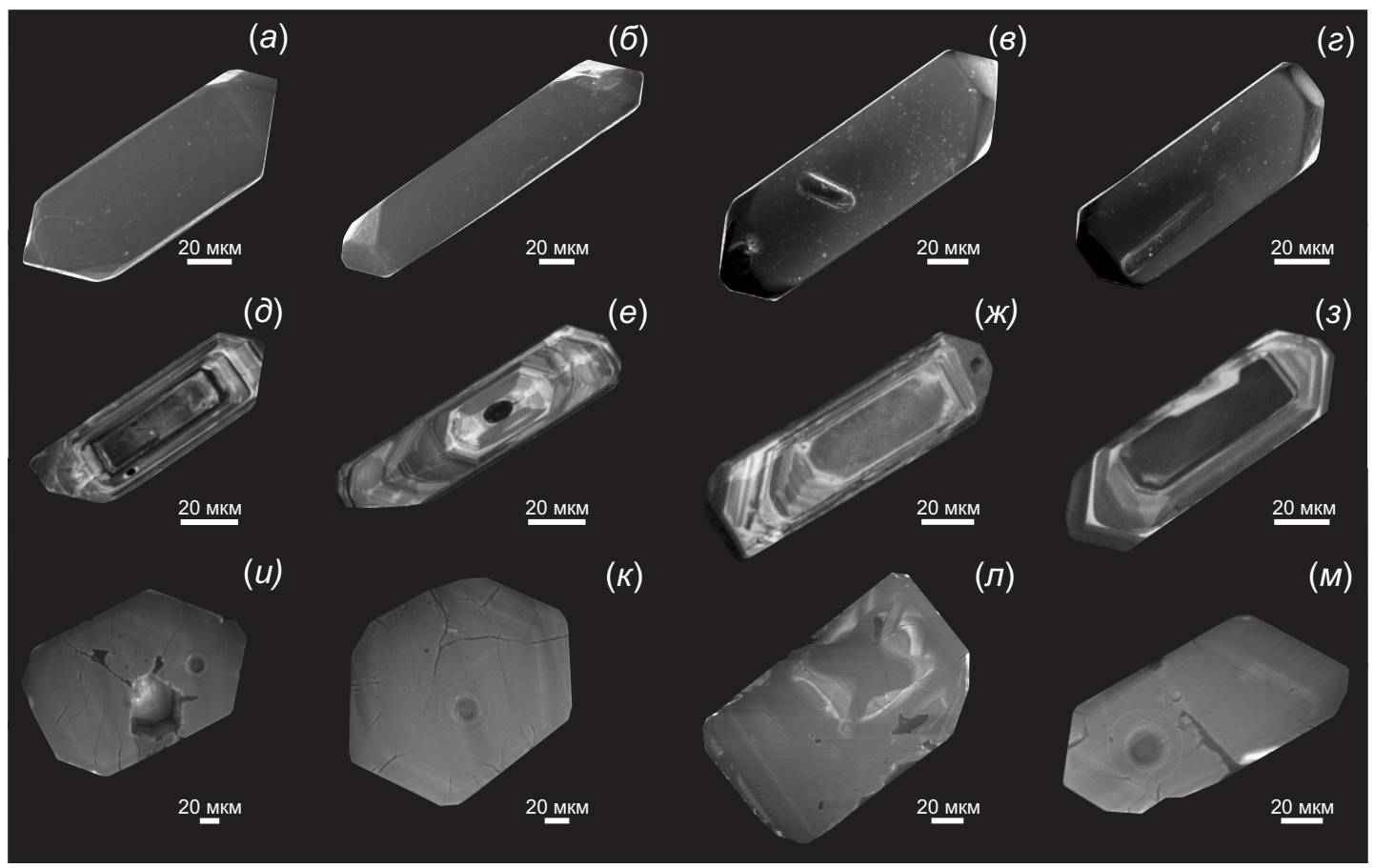

Рис. 7. Микрофотографии кристаллов циркона в режиме вторичных электронов $(a-2)$ и катодолюминесценции $(\partial-3)$ из биотит-роговообманковых порфиробластических кварцевых монцонитов (обр. С-1155) кивилийского комплекса и в режиме катодолюминесценции (u-M) из амфибол-биотитовых гнейсовидных гранитов (oбp. R-97) суларинского комплекса.

Fig. 7. Microphotographs of zircon crystals in the secondary electron mode $(a-2)$ and in the cathodoluminescence mode $(\partial-3)$ from biotite-hornblende porphyroblastic quartz monzonite of the Kivili complex (sample C-1155) and in the cathodoluminescence mode $(u-M)$ from amphibole-biotite gneiss-granite of the Sularin complex (sample R-97).

Таблица 2. Результаты U-Pb геохронологических исследований акцессорного циркона из кварцевого монцонита кивилийского комплекса (обр. C-1155)

Table 2. Results of $\mathrm{U}-\mathrm{Pb}$ geochronological studies of accessory zircon from quartz monzonite of the Kivili complex (sample C-1155)

\begin{tabular}{|c|c|c|c|c|c|c|c|c|c|c|c|c|}
\hline \multirow{2}{*}{$\begin{array}{c}\text { № обр./ } \\
\text { № фракции }\end{array}$} & \multirow{2}{*}{$\begin{array}{c}\text { Размер } \\
\text { фракции, мм, } \\
\text { навеска, мг }\end{array}$} & \multicolumn{2}{|c|}{$\begin{array}{c}\text { Содержание, } \\
\text { мкг/г }\end{array}$} & \multicolumn{5}{|c|}{ Изотопные отношения } & \multicolumn{4}{|c|}{ Возраст, млн лет } \\
\hline & & $\mathrm{Pb}$ & $\mathrm{U}$ & $\begin{array}{l}{ }^{206} \mathrm{~Pb} / \\
{ }^{204} \mathrm{~Pb}^{*}\end{array}$ & $\begin{array}{l}{ }^{207} \mathrm{~Pb} / \\
{ }^{206} \mathrm{~Pb}^{*}\end{array}$ & $\begin{array}{l}{ }^{208} \mathrm{~Pb} / \\
{ }^{206} \mathrm{~Pb}^{*}\end{array}$ & $\begin{array}{c}{ }^{206} \mathrm{~Pb} / \\
{ }^{238} \mathrm{U}\end{array}$ & $\begin{array}{c}{ }^{207} \mathrm{~Pb} / \\
{ }^{235} \mathrm{U}\end{array}$ & Rh & $\begin{array}{c}{ }^{206} \mathrm{~Pb} / \\
{ }^{238} \mathrm{U}\end{array}$ & $\begin{array}{c}{ }^{207} \mathrm{~Pb} / \\
{ }^{235} \mathrm{U}\end{array}$ & $\begin{array}{c}{ }^{207} \mathrm{~Pb} / \\
{ }^{206} \mathrm{~Pb}\end{array}$ \\
\hline $\mathrm{C}-1155 / 1$ & $-500+150,0.4$ & 24.8 & 302 & 283 & $0.10720 \pm 1$ & $0.2098 \pm 2$ & $0.07263 \pm 36$ & $0.5638 \pm 39$ & 0.51 & $452.0 \pm 2.3$ & $454.0 \pm 3.2$ & $464.3 \pm 8.2$ \\
\hline C-1155/2 & $-150+100,0.3$ & 25.1 & 293 & 346 & $0.09788 \pm 2$ & $0.2330 \pm 5$ & $0.07278 \pm 29$ & $0.5630 \pm 43$ & 0.43 & $452.9 \pm 1.8$ & $453.5 \pm 5.2$ & $456.7 \pm 9.1$ \\
\hline$C-1155 / 3$ & $-100+70,0.2$ & 34.0 & 411 & 421 & $0.09056 \pm 2$ & $0.1952 \pm 4$ & $0.07267 \pm 29$ & $0.5629 \pm 34$ & 0.45 & $452.2 \pm 1.8$ & $453.4 \pm 3.6$ & $459.4 \pm 5.1$ \\
\hline $\mathrm{C}-1155 / 4$ & $-70+50,0.7$ & 32.3 & 397 & 475 & $0.08666 \pm 4$ & $0.1866 \pm 9$ & $0.07272 \pm 14$ & $0.5639 \pm 39$ & 0.40 & $452.5 \pm 1.2$ & $454.1 \pm 5.4$ & $461.8 \pm 7.4$ \\
\hline
\end{tabular}

Примечание. * - изотопные отношения, скорректированные на бланк и обычный свинец; Rho - коэффициент корреляции ошибок отношений ${ }^{207} \mathrm{~Pb} /{ }^{235} \mathrm{U}-{ }^{206} \mathrm{~Pb} /{ }^{238} \mathrm{U}$. Величины ошибок $(2 \sigma)$ соответствуют последним значащим цифрам.

Note. * - isotopic ratios corrected for blank and normal lead; Rho - correlation coefficient of errors in ${ }^{207} \mathrm{~Pb} /{ }^{235} \mathrm{U}-{ }^{206} \mathrm{~Pb} /{ }^{238} \mathrm{U}$ ratios. Error values $(2 \sigma)$ correspond to the last significant digits after the decimal point.

\section{2. Амфибол-биотитовый гнейсовидный гранит суларинского комплекса (обр. R-97)}

Место отбора образца показано на рис. 1. Циркон, выделенный их этих пород, представлен полупрозрачными и прозрачными субидиоморфными, реже идиоморфными, часто трещиноватыми кристаллами призматического и короткопризматического облика. Они имеют коричневую окраску и пониженное двупреломление. Размер кристаллов циркона изменяется от 70 до 500 мкм; $K_{\text {удл. }}=2.5-3.0$. Для них характерна фрагментарно проявленная осцилляторная зональность и низкая интенсивность люминесценции (см. рис. $7, u-м)$.

Для проведения U-Th-Pb геохронологических исследований (LA-ICP-MS) было использовано 21 зерно циркона (табл. 3, рис. 8, б). Конкордантные оценки их возраста находятся в интервале 506-464 млн лет. Средневзвешенное значение возраста изученных цирконов составляет около 481 млн лет. Конечно, результаты проведенных исследований не позволяют достаточно 


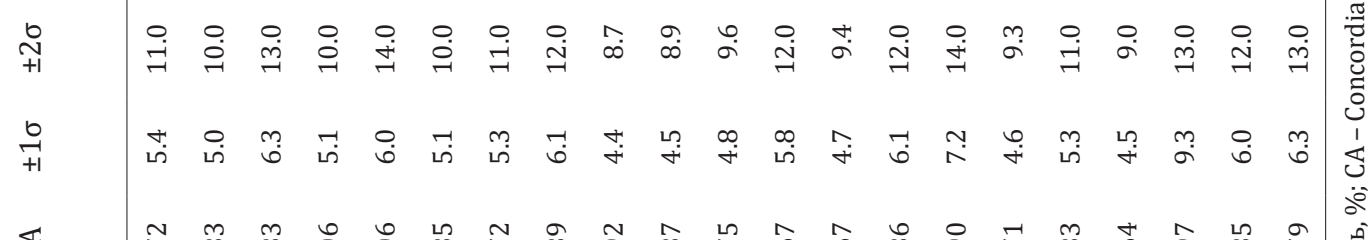

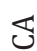

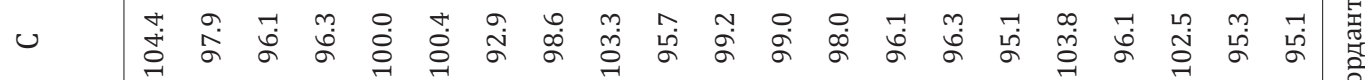

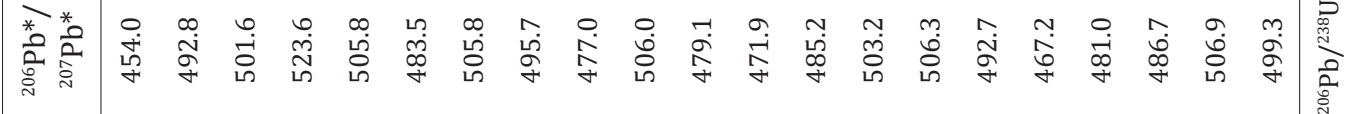

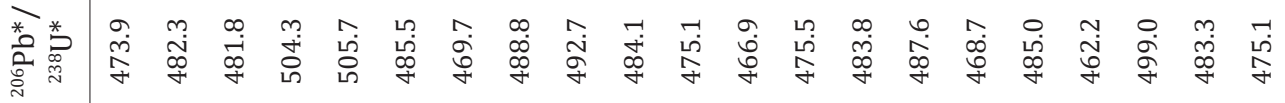

울

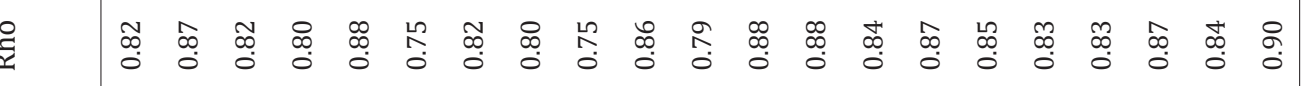
+1

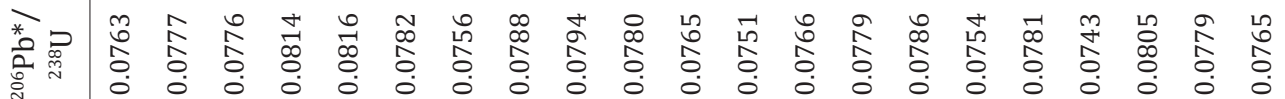
+1 ब $\rightarrow$ 广

녹 녹 공

ก

管䓪

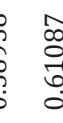

证

通

通

齐

+1 @

今.

$\infty$

i

$\stackrel{\circ}{\rightarrow}$

:

ֻ

$\stackrel{m}{-} \underset{-}{-1}$

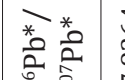

造总

忿

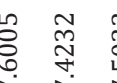

觉

这亮

趂

栾

苞

壱

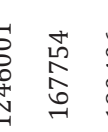

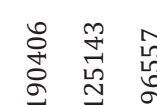

永

암

ก

तु

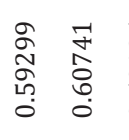

○

숭

豆

$\supset \frac{5}{\dot{s}}$

两

i

官

के

$\stackrel{\infty}{\stackrel{m}{\sigma}}$

ㅇํ

เก ลิ

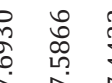

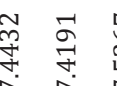

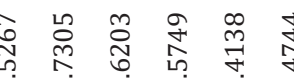

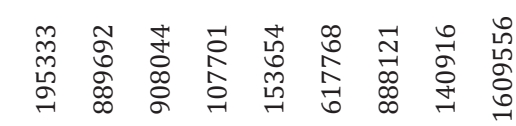

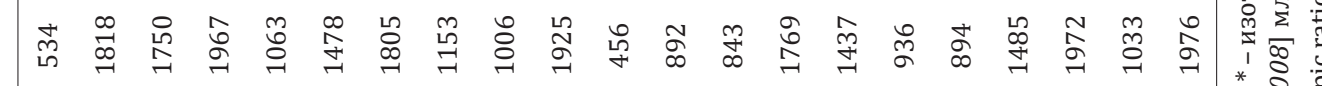


(a)

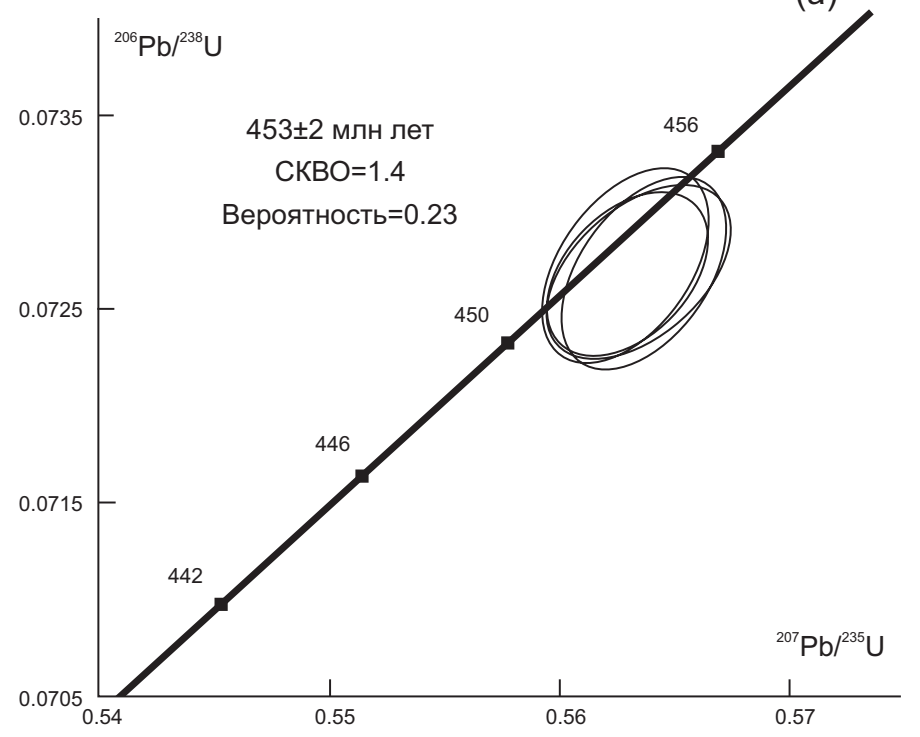

(б)

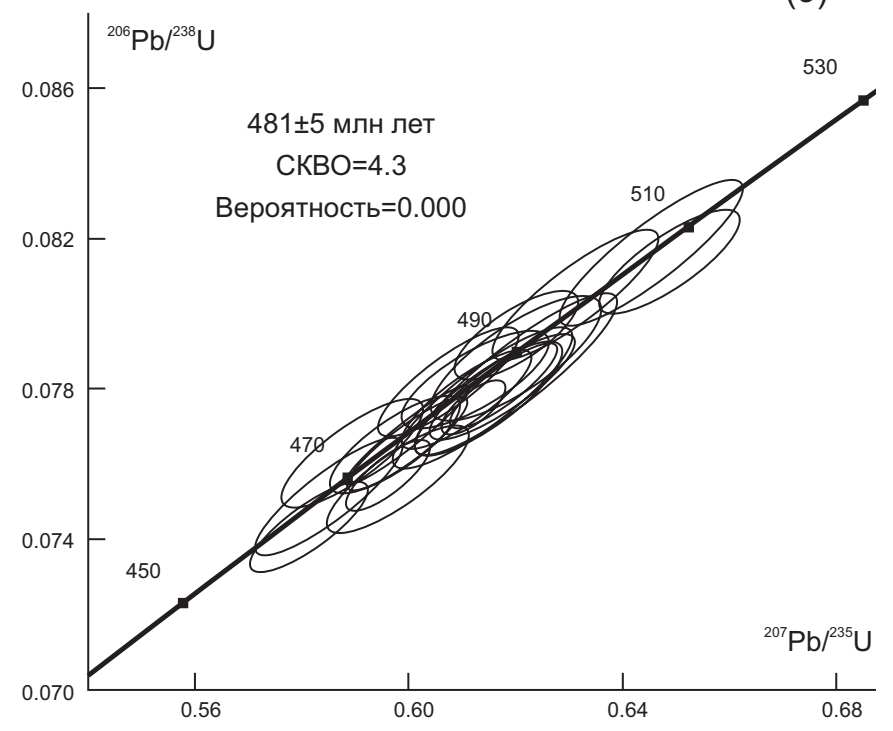

Рис. 8. Диаграммы с конкордией для циркона из биотит-роговообманковых порфиробластических кварцевых монцонитов (обр. C-1155) кивилийского комплекса (a) и амфибол-биотитовых гнейсовидных гранитов (обр. R-97) суларинского комплекса (б).

Первичные данные приведены в табл. 2, 3.

Fig. 8. Concordia diagrams for zircon from biotite-hornblende porphyroblastic quartz monzonite of the Kivili complex (sample C-1155) (a) and amphibole-biotite gneiss-granite of the Sularin complex (sample R-97) (б).

Primary data are given in Tables 2, 3 .

точно определить возраст гранитоидов суларинского комплекса, однако позволяют предполагать, что они несколько древнее кварцевых монцонитов кивилийского комплекса.

\section{6. РЕЗУЛЬТАТЫ SM-ND \\ ИЗОТОПНО-ГЕОХИМИЧЕСКИХ ИССЛЕДОВАНИЙ}

$\mathrm{Sm}-\mathrm{Nd}$ изотопно-геохимические исследования выполнены как для кварцевых монцонитов кивилийского комплекса, так и для гнейсовидных гранитов суларинского комплекса. Результаты приведены в табл. 4 и на рис. 9. Кварцевые монцониты кивилийского комплекса характеризуются отрицательными величинами $\varepsilon_{\mathrm{Nd}(\mathrm{t})}=-6.6 \ldots-7.7$ и палеопротерозойскими значениями $\mathrm{Nd}$ модельного возраста $\mathrm{t}_{\mathrm{Nd(DM)}}=1.9-$ 1.8 млрд лет, $\mathrm{t}_{\mathrm{Nd}(\mathrm{C})}=1.8-1.7$ млрд лет. В отличие от них граниты суларинского комплекса имеют более низкие значения $\varepsilon_{\mathrm{Nd}(\mathrm{t})}=-1.6$ и мезопротерозойские значения $\mathrm{Nd}$ модельного возраста $\mathrm{t}_{\mathrm{Nd}(\mathrm{DM})}=1.3$ млрд лет, $\mathrm{t}_{\mathrm{Nd}(\mathrm{C})}=1.4$ млрд лет.

\section{7. ОБСУЖДЕНИЕ РЕЗУЛЬТАТОВ}

В ходе проведенных геохронологических исследований установлено, что возраст порфиробластических кварцевых монцонитов кивилийского комплекса составляет $453 \pm 2$ млн лет (поздний ордовик), а гнейсовидных гранитов суларинского комплекса - около 481 млн лет (поздний кембрий). В первую очередь следует отметить, что эти данные противоречат существующим представлениям о том, что гранитоиды кивилийского комплекса древнее суларинского [Serezhnikov, Volkova, 2007; Petruk, Volkova, 2006; Zabrodin et al.,2007;
Vas'kin, Dymovich, 2009; Martynyuk et al., 1990]. Кроме того, согласно ранее полученным данным, возраст порфиробластических роговообманково-биотитовых гранитов Кивилийского массива одноименного комплекса составляет 474 1 млн лет [Sorokin et al., 2011a], а гнейсовидных гранитов центральной части Суларинского массива (см. рис. 1, обр. C-1150) одноименного

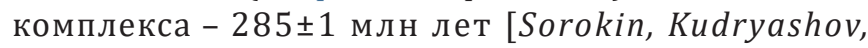
2012]. Это свидетельствует о том, что в составе обоих комплексов в настоящее время объединены разновозрастные породы, что является прямым следствием отсутствия четких критериев их выделения. В этой связи в процессе обсуждения целесообразно использовать возраст пород, а не их дискуссионную принадлежность к каким-либо комплексам.

Как было показано выше (табл. 4, рис. 9), позднекембрийские граниты характеризуются значениями $\mathrm{Nd}$ модельного возраста $\mathrm{t}_{\mathrm{Nd}(\mathrm{DM})}=1.3$ млрд лет, $\mathrm{t}_{\mathrm{Nd}(\mathrm{C})}=1.4$ млрд лет. В отличие от них, позднеордовикским кварцевым монцонитам свойственны существенно более древние значения $\mathrm{Nd}$ модельного возраста $\mathrm{t}_{\mathrm{Nd}(\mathrm{DM})}=1.9-1.8$ млрд лет, $\mathrm{t}_{\mathrm{Nd}(\mathrm{C})}=1.8-1.7$ млрд лет.

Из приведенных данных следует, что позднеордовикские кварцевые монцониты образовались преимущественно за счет коровых источников, обладающих палеопротерозойскими модельными изотопными возрастами. В качестве таких источников могли выступать кембрийские метаосадочные породы [Ovchinnikov et al., 2019], неопротерозойские ортогнейсы туловчихинской свиты [Sorokin et al., 2019], а также гранитоиды нятыгранского комплекса [Sorokin et al., 2017] (рис. 9). Значения $\mathrm{Nd}$ модельного возраста позднекембрийских 
Таблица 4. Результаты Sm-Nd изотопно-геохимических исследований магматических пород кивилийского и суларинского комплексов Буреинского континентального массива

Table 4. Results of Sm-Nd isotopic-geochemical studies of magmatic rocks of the Kivili and Sularin complexes of the Bureya continental massif

\begin{tabular}{|c|c|c|c|c|c|c|c|c|c|}
\hline Образец & $\begin{array}{l}\text { Возраст, } \\
\text { млн лет }\end{array}$ & $\begin{array}{c}\mathrm{Sm}, \\
\text { мкг/г }\end{array}$ & $\begin{array}{c}\mathrm{Nd}, \\
\text { мкг/г }\end{array}$ & ${ }^{147} \mathrm{Sm} /{ }^{144} \mathrm{Nd}$ & $\begin{array}{c}{ }^{143} \mathrm{Nd} /{ }^{144} \mathrm{Nd}^{*} \\
( \pm 2 \text { бизм.) }\end{array}$ & $\varepsilon_{\mathrm{Nd}(0)}$ & $\varepsilon_{\mathrm{Nd}(\mathrm{t})}$ & $\begin{array}{c}\mathrm{t}_{\mathrm{Nd(DM)}} \\
\text { млрд лет }\end{array}$ & $\begin{array}{l}\mathrm{t}_{\mathrm{Nd}(\mathrm{DM} 2-\mathrm{st})} \\
\text { млрд лет }\end{array}$ \\
\hline \multicolumn{10}{|c|}{ Порфиробластические кварцевые монцониты кивилийского комплекса } \\
\hline C-1155 & 453 & 12.44 & 59.50 & 0.1264 & $0.512093 \pm 2$ & -10.6 & -6.6 & 1843 & 1748 \\
\hline C-1155-1 & 453 & 12.89 & 62.77 & 0.1242 & $0.512031 \pm 2$ & -11.8 & -7.7 & 1901 & 1837 \\
\hline \multicolumn{10}{|c|}{ Гнейсовидные граниты суларинского комплекса } \\
\hline R-97 & 481 & 12.97 & 68.46 & 0.1145 & $0.512295 \pm 2$ & -6.7 & -1.6 & 1314 & 1362 \\
\hline
\end{tabular}

Примечание. * - погрешность $(2 \sigma)$ соответствует последним значащим цифрам после запятой.

Note. ${ }^{*}$ - error $(2 \sigma)$ corresponds to the last significant digits after the decimal point.

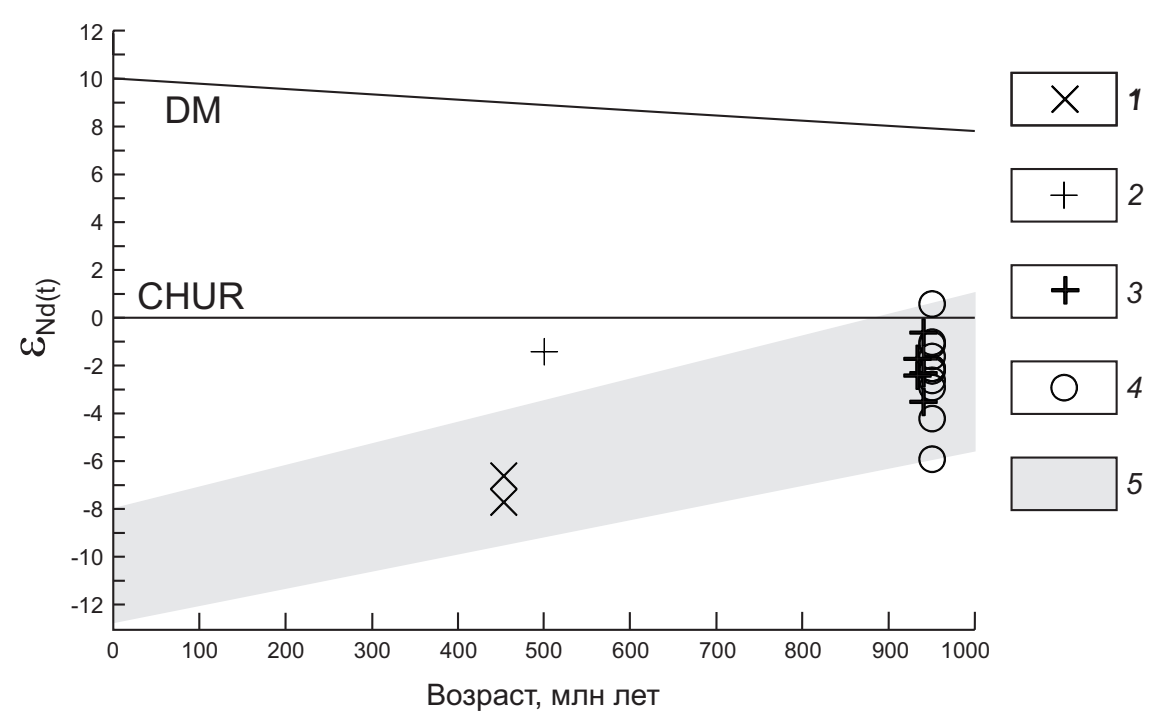

Рис. 9. Диаграмма $\varepsilon_{\mathrm{Nd}(\mathrm{t})}$ - возраст (млн лет) для валовых составов раннепалеозойских гранитоидов Буреинского континентального массива. DM - деплетированная мантия, CHUR - однородный хондритовый резервуар.

1 - позднеордовикские биотит-роговообманковые порфиробластические кварцевые монцониты кивилийского комплекса; 2 - позднекембрийские амфибол-биотитовые гнейсовидные граниты суларинского комплекса; 3 - неопротерозойские гранитоиды нятыгранского комплекса [Sorokin et al., 2017]; 4 - ортогнейсы туловчихинской свиты [Sorokin et al., 2019]; 5 - поле составов кембрийских осадков Мельгинского прогиба [Ovchinnikov et al., 2019].

Fig. 9. Plot of $\varepsilon_{\mathrm{Nd}(\mathrm{t})}$ versus crystallization age (Ma) for the Early Paleozoic igneous rocks of the Bureya continental massif. DM - depleted mantle, CHUR - homogeneous chondritic reservoir.

1 - Late Ordovician biotite-hornblende porphyroblastic quartz monzonite of the Kivili complex; 2 - Late Cambrian amphibole-biotite gneiss-granite of the Sularin complex; 3 - Neoproterozoic granitoids of the Nyatygran complex [Sorokin et al., 2017]; 4 - orthogneisses of the Tulovchikha formation [Sorokin et al., 2019]; 5 - field of Cambrian sediments of the Mel'gin Trough [Ovchinnikov et al., 2019].

гранитов (табл. 4, рис. 9) указывают на то, что в магмообразовании, наряду с древним коровым материалом, присутствовал более молодой источник.

На тектонических диаграммах Дж. Пирса (рис. 10, a-2) фигуративные точки составов рассматриваемых гранитоидов попадают в область неопределенности между полями составов гранитов островных дуг, зон коллизий и внутриплитных обстановок. При этом ближе к полю последних позднеордовикские кварцевые монцониты. На диаграммах Р. Батчелора и П. Боудена (рис. 10, д), а также С.Д. Великославинского (рис. 10, е) составы изученных гранитоидов образуют более обособленные поля. В частности, позднекембрийские граниты проявляют сходство с гранитами синколлизионных обстановок, а позднеордовикские кварцевые монцониты с гранитоидами позднеорогенных обстановок (рис. 10, д) или внутриплитных гранитоидов. В то же время мы понимаем, что к тектоническим выводам, основанным на геохимических особенностях пород, и в первую очередь гранитоидов, следует относиться с большой осторожностью.

Полученные данные, а также опубликованные ранее материалы позволяют наметить следующую последовательность проявления раннепалеозойского магматизма 
(a)
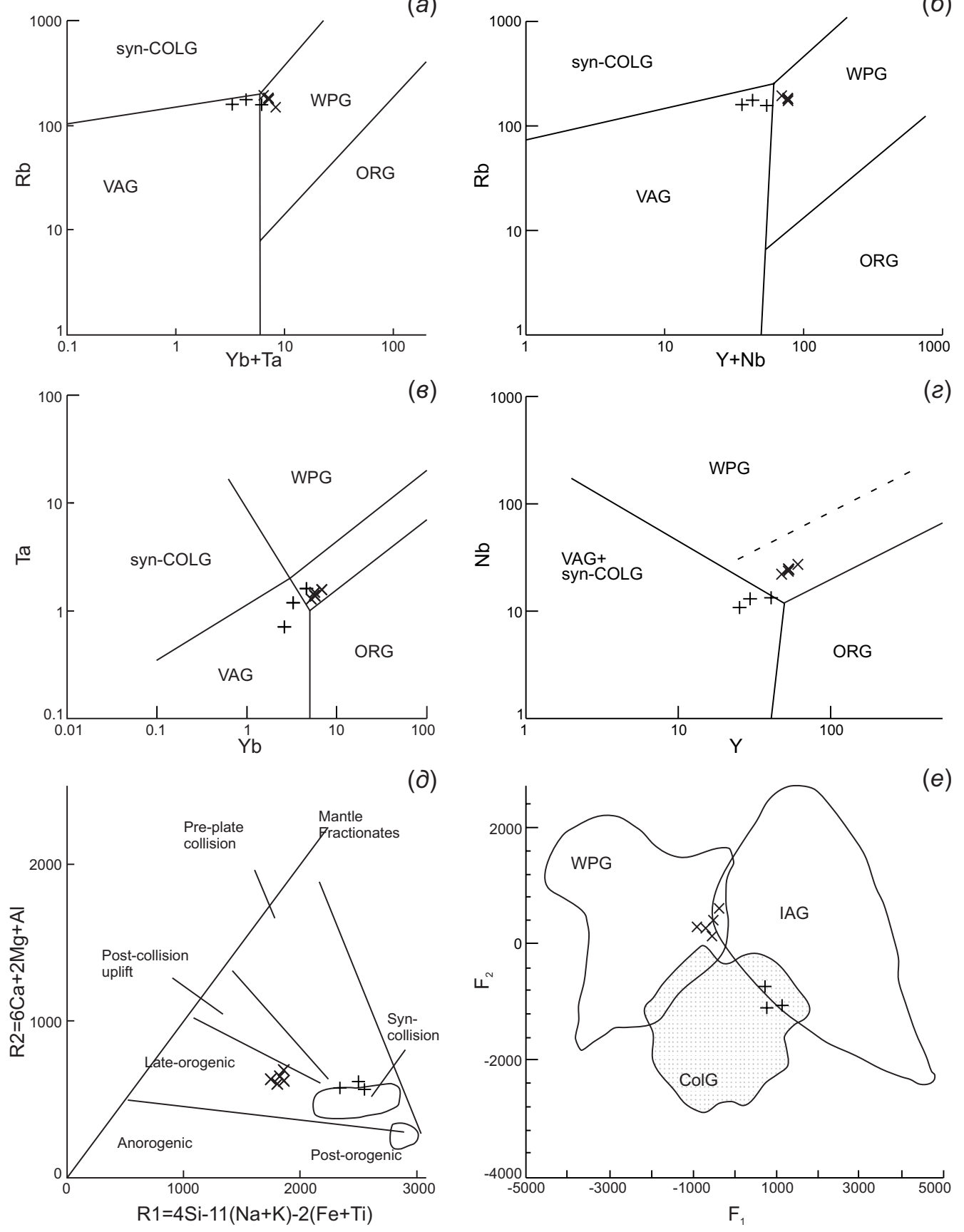

Рис. 10. Тектонические дискриминационные диаграммы (Yb+Ta) - Rb (a), (Y+Nb) - Rb (б), $\mathrm{Yb}-\mathrm{Ta}($ (в), $\mathrm{Y}-\mathrm{Nb}(2)[$ Pearce et al., 1984], R1 - R2 (d) [Batchelor, Bowden, 1985], F1-F2 (e) [Velikoslavinskii, 2003] для раннепалеозойских гранитоидов Буреинского континентального массива.

Поля на диаграммах: ORG - граниты океанических рифтов; VAG - граниты вулканических (островных) дуг; syn-COLG - cинколлизионные граниты; WPG - внутриплитные граниты; IAG - граниты зон субдукции. $\mathrm{F}_{1}=196.203 \mathrm{SiO}_{2}+753.953 \mathrm{TiO}_{2}+481.96 \mathrm{Al}_{2} \mathrm{O}_{3}+$ $92.664 \mathrm{FeO}^{*}+521.5 \mathrm{MgO}+374.766 \mathrm{CaO}+7.571 \mathrm{Na} 2 \mathrm{O}-584.778 \mathrm{~K}_{2} \mathrm{O}+0.379 \mathrm{Ba}-0.339 \mathrm{Sr}-0.733 \mathrm{Rb}-0.429 \mathrm{La}-3.33 \mathrm{Ce}-5.242 \mathrm{Nd}+$ $10.565 \mathrm{Sm}-19823.8 ; \mathrm{F}_{2}=1292.962 \mathrm{SiO}_{2}+4002.667 \mathrm{TiO}_{2}+1002.231 \mathrm{Al}_{2} \mathrm{O}_{3}+1297.136 \mathrm{FeO}^{*}+262.067 \mathrm{MgO}+1250.48 \mathrm{CaO}+1923.417 \mathrm{Na}_{2} \mathrm{O}+$ $1009.287 \mathrm{~K}_{2} \mathrm{O}+0.3634 \mathrm{Ba}-0.325 \mathrm{Sr}-0.701 \mathrm{Rb}+0.8015 \mathrm{La}+3.347 \mathrm{Ce}+2.68 \mathrm{Nd}+10.11 \mathrm{Sm}-126860.0 ; \mathrm{SiO}_{2}+\mathrm{TiO}_{2}+\mathrm{Al}_{2} \mathrm{O}_{3}+\mathrm{FeO}+\mathrm{MgO}+\mathrm{CaO}+\mathrm{Na}{ }_{2} \mathrm{O}+$ $\mathrm{K}_{2} \mathrm{O}+\mathrm{P}_{2} \mathrm{O}_{5}=100 \% ; \mathrm{FeO}^{*}=0.9 \mathrm{Fe}_{2} \mathrm{O}_{3}+\mathrm{FeO}$. Содержания оксидов в мас. \%, малых элементов - в ррт. Условные обозначения как на рис. 3 .

Fig. 10. Tectonic discrimination diagrams (Yb+Ta) - Rb (a), ( $\mathrm{Y}+\mathrm{Nb})-\mathrm{Rb}($ б), $\mathrm{Yb}-\mathrm{Ta}(8), \mathrm{Y}-\mathrm{Nb}($ (2) [Pearce et al., 1984$], \mathrm{R} 1$ - $\mathrm{R} 2$ (d) [Batchelor, Bowden, 1985], F1-F2 (e) [Velikoslavinskii, 2003] for the Early Paleozoic igneous rocks of the Bureya continental massif.

Fields: ORG - oceanic-rift granites; VAG - volcanic(island)-arc granites; syn-COLG - syncollisional granites; WPG - within-plate granites; IAG - granites of subduction zones. $\mathrm{F}_{1}=196.203 \mathrm{SiO}_{2}+753.953 \mathrm{TiO}_{2}+481.96 \mathrm{Al}_{2} \mathrm{O}_{3}+92.664 \mathrm{FeO}^{*}+521.5 \mathrm{MgO}^{2}+374.766 \mathrm{CaO}^{2}+7.571 \mathrm{Na}_{2} \mathrm{O}-$ $584.778 \mathrm{~K}_{2} \mathrm{O}+0.379 \mathrm{Ba}-0.339 \mathrm{Sr}-0.733 \mathrm{Rb}-0.429 \mathrm{La}-3.33 \mathrm{Ce}-5.242 \mathrm{Nd}+10.565 \mathrm{Sm}-19823.8 ; \mathrm{F}_{2}=1292.962 \mathrm{SiO}_{2}+4002.667 \mathrm{TiO}+$ $1002.231 \mathrm{Al}_{2} \mathrm{O}_{3}+1297.136 \mathrm{FeO}^{*}+262.067 \mathrm{MgO}+1250.48 \mathrm{CaO}+1923.417 \mathrm{Na}_{2} \mathrm{O}+1009.287 \mathrm{~K}_{2} \mathrm{O}+0.3634 \mathrm{Ba}-0.325 \mathrm{Sr}-0.701 \mathrm{Rb}+0.8015 \mathrm{La}+$ $3.347 \mathrm{Ce}+2.68 \mathrm{Nd}+10.11 \mathrm{Sm}-126860.0 ; \mathrm{SiO}_{2}+\mathrm{TiO}_{2}+\mathrm{Al}_{2} \mathrm{O}_{3}+\mathrm{FeO}^{*}+\mathrm{MgO}+\mathrm{CaO}+\mathrm{Na}_{2} \mathrm{O}+\mathrm{K}_{2} \mathrm{O}+\mathrm{P}_{2} \mathrm{O}_{5}=100 \% ; \mathrm{FeO}^{*}=0.9 \mathrm{Fe}_{2} \mathrm{O}_{3}+\mathrm{FeO}_{\text {. Major elements }}$ are given in wt\%, trace elements, in ppm. Designations follow Fig. 3. 
в истории геологического развития Буреинского континентального массива:

504 млн лет - риолиты [Sorokin et al., 2011b];

481 млн лет - гнейсовидные граниты (данная статья);

$\sim 474$ млн лет - порфиробластические граниты [Sorokin et al., 2011a];

453 млн лет - порфиробластические кварцевые монцониты (данная статья).

Кроме того, следует иметь в виду, что наиболее молодые и одновременно наиболее многочисленные популяции детритовых цирконов в метатерригенных отложениях Буреинского континентального массива имеют возраст:

541-487 млн лет (дягдаглейская толща [Ovchinnikov et al., 2020]);

500 млн лет (туранская серия [Sorokin et al., 2014]).

Таким образом, главными рубежами проявления раннепалеозойского гранитоидного магматизма Буреинского континентального массива являются: 541, 2504-500, 487, 474, 453 млн лет.

Достаточно близкие оценки возраста получены для магматических комплексов соседнего с Буреинским Цзямусинского массива [Kotov et al., 2009; Sorokin et al., 2010b, 2011c; Buchko et al., 2012; Smirnova et al., 2016; Yang et al., $2014,2018]$. Кроме того, согласно ранее проведенным исследованиям, позднекембрийские и раннеордовикские гранитоиды Цзямусинского континентального массива по своим геохимическим особенностям близки к коллизионным, а средне- и позднеордовикские - к постколлизионным гранитоидам [Sorokin et al., 2011c]. Это хорошо согласуется с представленными материалами и позволяет сделать заключение о том, что раннепалеозойский магматизм в пределах Буреинского и Цзямусинского массивов был проявлен практически синхронно в интервале с кембрия по силур. Наряду с синхронностью

\section{0. ЛИТЕРАТУРA/REFERENCES}

Batchelor R.A., Bowden P., 1985. Petrogenetic interpretation of granitoid rock series using multicationic parameters. Chemical Geology 48 (1-4), 43-55. https://doi.org/10. 1016/0009-2541(85)90034-8.

Buchko I.V., Sorokin A.A., Kudryashov N.M., 2012. Age and tectonic position of the Early Paleozoic Malyi Khingan Terrane in the Eastern part of the Central Asian fold belt. Doklady Earth Sciences 445 (2), 929-933. https://doi.org/10. 1134/S1028334X12080028.

Didenko A.N., Mossakovskiy A.A., Pecherskiy D.M., Ruzhentsev S.V., Samygin S.G., Kheraskova T.N., 1994. Geodynamics of the Paleozoic oceans of the Central Asia. Geology and Geophysics 35 (7-8), 59-75 (in Russian) [Диденко A.H., Моссаковский А.А., Печерский Д.М., Руженцев С.В., Самыгин С.Г., Хераскова Т.Н. Геодинамика палеозойских океанов Центральной Азии // Геология и геофизика. 1994. T. 35. № 7-8. С. 59-75].

Jahn B.M., 2004. The Central Asian Orogenic Belt and growth of the continental crust in the Phanerozoic. In: J. Malpas, C.J.N. Fletcher, J.R. Ali, J.C. Aitchison (Eds), Aspects of the Tectonic Evolution of China. Geological Society, London, неопротерозойского магматизма [Luan et al., 2017a, 2017b; Sorokin et al., 2017] это указывает на общую геологическую историю этих массивов.

\section{8. ЗАКЛЮЧЕНИЕ}

Установлено, что возраст порфиробластических кварцевых монцонитов кивилийского комплекса составляет 453 2 млн лет, а гнейсовидных гранитов суларинского комплекса может быть оценен только приблизительно - около 481 млн лет.

Позднеордовикские порфиробластические кварцевые монцониты образовались преимущественно за счет коровых источников, обладающих палеопротерозойскими модельными изотопными возрастами. В формировании кембрийских гранитов принимал участие как древний (палеопротерозойский?), так и более молодой источник.

Накопленные к настоящему времени геохронологические данные позволяют выделить следующие главные импульсы проявления раннепалеозойского магматизма Буреинского и Цзямусинского континентальных массивов: 541, 504-500, 487, 474, 453 млн лет. С учетом синхронности проявления неопротерозойского магматизма в их пределах это свидетельствует о их общей геологической истории.

\section{9. БЛАГОДАРНОСТИ}

Авторы благодарят сотрудников аналитических лабораторий Института геологии и природопользования ДВО РАН - Е.Н. Воропаеву, О.Г. Медведеву, А.И. Палажченко, В.И. Рождествину, Е.С. Сапожник, Е.В. Ушакову; Института тектоники и геофизики ДВО РАН - Е.М. Голубеву, А.В. Штареву, Л.С. Боковенко, а также Центра LaserChron Университета штата Аризона (США) за проведение аналитических исследований.

Special Publications, vol. 226, p. 73-100. https://doi.org/ 10.1144/GSL.SP.2004.226.01.05.

Khanchuk A.I., 2000. Paleogeodynamic analysis of ore deposit formation in the Russian Far East. In: A.I. Khanchuk (Ed.), Ore deposits of continental margins. Dal'nauka, Vladivostok, p. 5-34 (in Russian) [Ханчук А.И. Палеогеодинамический анализ формирования рудных месторождений Дальнего Востока России // Рудные месторождении континентальных окраин / Ред. А.И. Ханчук. Владивосток: Дальнаука, 2000. C. 5-34].

Khanchuk A.I. (Ed.), 2006. Geodynamics, Magmatism, and Metallogeny of Eastern Russia. Book 1. Dal'nauka, Vladivostok, 572 p. (in Russian) [Геодинамика, магматизм и металлогения востока России. Книга 1 / Ред. А.И. Ханчук. Владивосток: Дальнаука, 2006. 572 с.].

Kotov A.B., Sorokin A.A., Sal'nikova E.B., Sorokin A.P., Velikoslavinskii S.D., Anisimova I.V., Yakovleva S.Z., 2009. Early Paleozoic age of gabbroids of the amur complex (BureyaJiamusi Superterrane of the Central Asian Fold Belt). Doklady Earth Sciences 425 (1), 185-188. https://doi.org/10. 1134/s1028334x09020019. 
Kröner A., 2015. The Central Asian Orogenic Belt. Geology, Evolution, Tectonics, and Models. Borntraeger Science Publishers, Stuttgart, 313 p.

Le Maitre R.W., Streckeisen A., Zanettin B., Le Bas M.J., Bonin B., Bateman P., Bellieni G., Dudek A., Efremova S., Keller J., Lameyre J., Sabine P.A., Schmid R., Sorensen H., Woolley A.R., 2002. Igneous Rokcs. A Classification and Glossary of Terms: Recommendations of the Internationsl Union of Geological Sciences Subcommission on the Systematics of Igneous Rocks. Cambridge University Press, Cambridge, 236 p. https://doi.org/10.1017/CB09780511535581.

Luan J.P., Wang F., Xu W.L., Ge W.C., Sorokin A.A., Wang Z.W., Guo P., 2017a. Provenance, age, and tectonic implications of Neoproterozoic strata in the Jiamusi Massif: Evidence from $\mathrm{U}-\mathrm{Pb}$ ages and $\mathrm{Hf}$ isotope compositions of detrital and magmatic zircons. Precambrian Research 297, 19-32. https:// doi.org/10.1016/j.precamres.2017.05.012.

Luan J.-P., Xu W.-L., Wang F., Wang Z.-W., Guo P., 2017b. Age and geochemistry of Neoproterozoic granitoids in the Songnen-Zhangguangcai Range Massif, NE China: Petrogenesis and tectonic implications. Journal of Asian Earth Sciences 148, 265-276. https://doi.org/10.1016/j.jseaes. 2017.09.011.

Ludwig K.R., 2008. Isoplot 3.6. Berkeley Geochronology Center Special Publication, vol. 4, 77 p.

Maniar P.D., Piccoli P.M., 1989. Tectonic discrimination of granitoids. Geological Society of America Bulletin 101 (5), 635-643. https://doi.org/10.1130/0016-7606(1989) 101<0635:TDOG>2.3.CO;2.

Martynyuk M.V., Ryamov S.A., Kondrat'eva V.A., 1990. Explanatory Note to the Correlation Scheme for Igneous Complexes of the Khabarovsk Territory and Amur Region. Dal'geologia, Khabarovsk, 215 p. (in Russian) [Мартынюк М.В., Рямов С.А., Кондратьева В.А. Объяснительная записка к схеме корреляции магматических комплексов Хабаровского края и Амурской области. Хабаровск: Дальгеология, 1990. 215 с.].

McDonough W.F., Sun S.S., 1995. The composition of the Earth. Chemical Geology 120 (3-4), 223-253. https://doi. org/10.1016/0009-2541(94)00140-4.

Mossakovsky A.A., Ruzhentsev S.V., Samygin S.G., Kheraskova T.N., 1993. Central Asian Fold belt: geodynamic evolution and history of formation. Geotektonika (Geotectonics) (6), 3-32 (in Russian) [Моссаковский А.А., Руженцев C.В., Самыгин С.Г., Хераскова Т.Н. Центрально-Азиатский складчатый пояс: геодинамическая эволюция и история формирования // Геотектоника. 1993. № 6. С. 3-32].

Ovchinnikov R.O., Sorokin A.A., Kovach V.P., Kotov A.B., 2020. Ages and nature of the protolith of the metamorphic rocks of the Dyagdagle formation (Bureya continental massif of the Central Asian Fold Belt). Stratigraphy and Geological Correlation (in press).

Ovchinnikov R.O., Sorokin A.A., Kudryashov N.M., 2018. Age of the Early Precambrian (?) intrusive complexes of the Northern Bureya Continental Massif, Central Asian Fold Belt. Russian Journal of Pacific Geology 12 (4), 289-302. https:// doi.org/10.1134/S181971401804005X.

Ovchinnikov R.O., Sorokin A.A., Xu W.L., Yang H., Kovach V.P., Kotov A.B., Plotkina Yu.V., 2019. Provenance and tectonic implications of Cambrian sedimentary rocks in the Bureya Massif, Central Asian Orogenic Belt, Russia. Journal of Asian Earth Sciences 172, 393-408. https://doi.org/10.1016/j. jseaes.2018.10.001.

Parfenov L.M., Berzin N.A., Khanchuk A.I., Badarch G., Belichenko V.G., Bulgatov A.N., Dril' S.I., Kirillova G.L., Kuz'min M.I., Nokleberg W., Prokop'ev A.V., Timofeev V.F., Tomurtogoo O., Yan H., 2003. A model for the formation of orogenic belts of Central and Northeast Asia. Tikhookeanskaya Geologiya 22 (6), 7-41 (in Russian) [Парфенов Л.М., Берзин Н.А., Ханчук А.И., Бодарч Г., Беличенко В.Г., Булгатов А.Н., Дриль С.И., Кириллова Г.Л., Кузьмин М.И., Ноклеберг У.Дж., Прокопьев А.В., Тимофеев В.Ф., Томуртогоо О., Янь Х., 2003. Модель формирования орогенных поясов Центральной и Северо-Восточной Азии // Тихоокеанская геология. 2003. Т. 22. № 6. С. 7-41.

Pearce J.A., Harris N.B.W., Tindle A.G., 1984. Trace element discrimination diagrams for the tectonic interpretation of granitic rocks. Journal of Petrology 25 (4), 956-983. https://doi.org/10.1093/petrology/25.4.956.

Petruk N.N., Volkova Yu.R., 2006. State Geological Map of the Russian Federation 1:1000000. Far Eastern Series. Sheet M-52. VSEGEI, Saint Petersburg (in Russian) [Петрук Н.Н., Волкова Ю.Р. Государственная геологическая карта Российской Федерации. Масштаб 1:1000000. Серия Дальневосточная. Лист М-52. СПб.: ВСЕГЕИ, 2006].

Resolutions of the IV Interdepartmental Regional Stratigraphical Conference on the Precambrian and Phanerozoic of the Southern Part of the Russian Far East and Eastern Transbaikalia, 1994. A set of schemes. Dal'geologiya, Khabarovsk (in Russian) [Решения IV Межведомственного регионального стратиграфического совещания по докембрию и фанерозою юга Дальнего Востока и Восточного Забайкалья. Комплект схем. Хабаровск: Дальгеология, 1994].

Şengör A.M.C., Natal'in B.A., 1996. Paleotectonics of Asia: fragments of a synthesis. In: A. Yin, T.M. Harrison (Eds), The tectonic evolution of Asia. Cambridge University Press, Cambridge, p. 486-640.

Serezhnikov A.N., Volkova Yu.R., 2007. State Geological Map of the Russian Federation. Scale 1:1000000. Far-Eastern Series. Sheet N-52 (Zeya). VSEGEI, Saint Petersburg (in Russian) [Сережников А.Н., Волкова Ю.Р. Государственная геологическая карта Российской Федерации. Масштаб 1:1000000. Серия Дальневосточная. Лист N-52 (Зея). СПб.: ВСЕГЕИ, 2007].

Sharpenok L., Kostin A., Kukharenko E., 2013a. Diagram "alkali sum - silica" (TAS) for chemical classification and diagnostics of plutonic rocks. Geophysical Research Abstracts 15, EGU2013-13518-1. Available from: https://meetingorga nizer.copernicus.org/EGU2013/EGU2013-13518-1.pdf.

Sharpenok L.N., Kostin A.E., Kukharenko E.A., 2013b. TotalAlkali-silica TAS diagram for chemical classification and identification of plutonic rocks. Regional'naya Geologya i Metallogeniya (56), 40-50 (in Russian) [Шарпенок Л.Н., Костин A.E., Кухаренко E.A. TAS-диаграмма сумма щелочей - кремнезем для химической классификации и диагностики плутонических пород // Региональная геология и металлогения. 2013. № 56. С. 40-50]. 
Smirnova Yu.N., Sorokin A.A., Kotov A.B., Kovach V.P., 2016. Tectonic conditions of sedimentation and source areas of Upper Proterozoic and Lower Paleozoic terrigenous deposits of the Lesser Khingan Terrane of the Central Asian Fold Belt. Stratigraphy and Geological Correlation 24 (3), 219241. https: //doi.org/10.1134/S0869593816030060.

Sorokin A.A., Kotov A.B., Kudryashov N.M., Kovach V.P., 2016. Early Mesozoic granitoid and rhyolite magmatism of the Bureya Terrane of the Central Asian Orogenic Belt: Age and geodynamic setting. Lithos 261, 181-194. https://doi. org/10.1016/j.lithos.2016.03.008.

Sorokin A.A., Kotov A.B., Sal'nikova E.B., Anisimova I.V., Yakovleva S.Z., Fedoseenko A.M., Kudryashov N.M., 2010a. Granitoids of the Tyrma-Bureya complex in the northern Bureya-Jiamusi superterrane of the Central Asian Fold Belt: age and geodynamic setting. Russian Geology and Geophysics 51 (5), 563-571. https://doi.org/10.1016/j.rgg.2010.04.011.

Sorokin A.A., Kotov A.B., Sal'nikova E.B., Kudryashov N.M., Velikoslavinskii S.D., Yakovleva S.Z., Fedoseenko A.M., Plotkina Yu.V., 2011c. Early paleozoic granitoids in the Lesser Khingan terrane, Central Asian Fold Belt: age, geochemistry, and geodynamic interpretations. Petrology 19 (6), 601-617. https://doi.org/10.1134/s0869591111060051.

Sorokin A.A., Kotov A.B., Sal'nikova E.B., Sorokin A.P., Yakovleva S.Z., Plotkina Yu.V., Gorokhovskii B.M., 2011a. The early paleozoic age of granitoides of the Kiviliyskii complex of the Bureya terrane (Eastern flank of the Central Asian Fold Belt). Doklady Earth Sciences 440 (1), 1253-1257. https://doi. org/10.1134/s1028334x11090327.

Sorokin A.A., Kotov A.B., Sal'nikova E.B., Sorokin A.P., Yakovleva S.Z., Fedoseenko A.M., Plotkina Yu.V., 2010b. First data on the age of Early Paleozoic granitoids from the Malyi Khingan terrane of the Central Asian Fold Belt. Doklady Earth Sciences 431 (1), 299-303. https://doi.org/10.1134/s102 8334x10030074.

Sorokin A.A., Kudryashov N.M., 2012. The first geochronological evidence for Late Paleozoic granitoid magmatism in the Bureya terrane (East of the Central Asian Fold Belt). Doklady Earth Sciences 447 (2), 1292-1296. https://doi. org/10.1134/s1028334x12120136

Sorokin A.A., Kudryashov N.M., Kotov A.B., 2007. Age and geochemistry of the Early Mesozoic granitoid massifs of the southern Bureya terrane of the Russian Far East. Russian Journal of Pacific Geology 1 (5), 454-463. https://doi.org/ 10.1134/S1819714007050053.

Sorokin A.A., Ovchinnikov R.O., Kudryashov N.M., Kotov A.B., Kovach V.P., 2017. Two stages of Neoproterozoic magmatism in the evolution of the Bureya continental massif of the Central Asian Fold Belt. Russian Geology and Geophysics 58 (10), 11711187. https://doi.org/10.1016/j.rgg.2016.12.009.

Sorokin A.A., Ovchinnikov R.O., Xu W., Kovach V.P., Yang H., Kotov A.B., Ponomarchuk V.A., Travin A.V., Plotkina Yu. V., 2019. Ages and nature of the protolith of the Tulovchikha metamorphic complex in the Bureya Massif, Central Asian Orogenic Belt, Russia: Evidence from U-Th-Pb, Lu-Hf, Sm-Nd and ${ }^{40} \mathrm{Ar} /{ }^{39} \mathrm{Ar}$ data. Lithos 332-333, 340-354. https://doi. org/10.1016/j.lithos.2019.03.001.

Sorokin A.A., Smirnov Yu.V., Kotov A.B., Kovach V.P., 2014. Age and source of terrigenous rocks of the turan group of the
Bureya Terrane of the eastern part of the Central Asian Fold Belt: Results of geochemical (Sm-Nd) and geochronological (U-Pb LA-ICP-MS) studies. Doklady Earth Sciences 456 (2), 759-763. https://doi.org/10.1134/s1028334x14060397.

Sorokin A.A., Smirnov Yu.V., Smirnova Yu.N., Kudryashov N.M., 2011 b. First data on age of metarhyolites from the Turan Group of the Bureya Terrane, eastern part of the Central Asian Fold Belt. Doklady Earth Sciences 439 (1), 944-948. https://doi.org/10.1134/S1028334X11070282.

Sun S.-S., McDonough W.F., 1989. Chemical and isotopic systematic of oceanic basalts: implications for mantle composition and processes. Geological Society, London, Special Publications 42, 313-345. https://doi.org/10.1144/GSL.SP. 1989.042.01.19.

Vas'kin A.F., 1984. Geological Map of the Baikal-Amur Railroad Region. Scale 1:500000. Sheet N-53-B. VSEGEI, Leningrad (in Russian) [Васькин А.Ф. Геологическая карта региона БАМ. Масштаб 1:500000. Лист N-53-Б. Л.: ВСЕГЕИ, 1984].

Vas'kin A.F., Dymovich V.A., 2009. State Geological Map of the Russian Federation. Scale 1:1000000. Far Eastern Series. Sheet M-53 (Khabarovsk). VSEGEI, Saint Petersburg (in Russian] [Васькин А.Ф., Дымович В.А. Государственная геологическая карта Российской Федерации. Масштаб 1:1000000. Серия Дальневосточная. Лист М-53 (Хабаровск). СПб.: ВСЕГЕИ, 2009].

Vasil'eva V.V., 1960. The State Geological Map of the USSR. Khingan-Bureya Series. Scale 1:200000. Sheet M-52-XVIII. VSEGEI, Leningrad (in Russian) [Васильева В.В. Геологическая карта СССР. 1:200000. Серия Хингано-Буреинская. Лист М-52-XVIII. Л.: ВСЕГЕИ, 1960].

Velikoslavinskii S.D., 2003. Geochemical classification of silicic igneous rocks of major geodynamic environments. Petrology 11 (4), 327-342.

Yang H., Ge W.C., Bi J.H., Wang Z.H., Tian D.X., Dong Y., Chen H.J., 2018. The Neoproterozoic - early Paleozoic evolution of the Jiamusi Block, NE China and its East Gondwana connection: Geochemical and zircon $\mathrm{U}-\mathrm{Pb}-\mathrm{Hf}$ isotopic constraints from the Mashan Complex. Gondwana Research 54, 102-121. https://doi.org/10.1016/j.gr.2017.10.002.

Yang H., Ge W.C., Zhao G.C., Dong Y., Bi J.H., Wang Z.H., Yu J.J., Zhang Y.L., 2014. Geochronology and geochemistry of Late Pan-African intrusive rocks in the Jiamusi-Khanka Block, NE China: Petrogenesis and geodynamic implications. Lithos 208-209, 220-236. https://doi.org/10.1016/j.lithos. 2014.09.019.

Yarmoluk V.V., Kozlovsky A.M., Kovach V.P., Kozakov I.K., Kotov A.B., Rytsk E.Y., 2012. Mechanisms of continental crust formation in the Central Asian Foldbelt. Geotectonic 46 (4), 251-272. https://doi.org/10.1134/s00168521 $1204005 x$.

Zabrodin V.Yu., Borodin A.M., Gur'yanov V.A., Zelepugin V.N., Kislyakov S.G., Kremenetskaya N.A., Makhinin A.V., Frolov F.S., Shvarev M.M., 2007. State Geological Map of the Russian Federation. Scale 1:1000000. Far Eastern Series. Sheet N-53 (Shantar Islands). VSEGEI, Saint Petersburg (in Russian) [Забродин В.Ю., Бородин А.М., Гурьянов В.А., Зелепугин В.Н., Кисляков С.Г., Кременецкая Н.А., Махинин А.В., Фролов Ф.С., Шварев М.М. Государственная геологическая карта Российской Федерации. Масштаб 
1:1000000. Серия Дальневосточная. Лист N-53 (Шантарские острова). СПб.: ВСЕГЕИ, 2007].

Zhou J.B., Wilde S.A., 2013. The crustal accretion history and tectonic evolution of the NE China segment of the Central Asian Orogenic Belt. Gondwana Research 23 (4), 13561377. https://doi.org/10.1016/j.gr.2012.05.012.

Zhou J.B., Wilde S.A., Zhao G.C., Han J., 2018. Nature and assembly of microcontinental blocks within the Paleo-Asian Ocean. Earth-Science Reviews 186, 76-93. https://doi.org/ 10.1016/j.earscirev.2017.01.012.
Zubkov V.F., Turbin M.T., 1984. Geological Map of the Baikal-Amur Railroad Region. Scale 1:500000. Sheet N-52-Г. VSEGEI, Leningrad (in Russian) [Зубков В.Ф., Турбин М.T. Геологическая карта региона БАМ. 1:500000. Лист N52-Г. Л.: ВСЕГЕИ, 1984].

Zubkov V.F., Vas'kin A.F., 1984. Geological Map of the Baikal-Amur Railroad Region. Scale 1:500000. Sheet M-52-Б. VSEGEI, Leningrad (in Russian) [Зубков В.Ф., Васькин А.Ф. Геологическая карта региона БАМ. 1:500000. Лист М52-Б. Л.: ВСЕГЕИ, 1984].

\section{ROMAN O. OVCHINNIKOV}

Junior Researcher

Institute of Geology and Nature Management FEB RAS

1 Relochniy Ln, Blagoveschensk 675000, Russia

e-mail: ovchinnikov@ignm.ru

ORCID: 0000-0003-0169-6460

\section{ANDREY A. SOROKIN}

Doctor of Geology and Mineralogy, Corresponding Member of RAS, Head of laboratory, Director Institute of Geology and Natural Management, FEB RAS

1 Relochniy Ln, Blagoveschensk 675000, Russia

e-mail: sorokin@ascnet.ru

ORCID: 0000-0002-8879-5412

\section{NIKOLAI M. KUDRYASHOV}

Candidate of Geology and Mineralogy, Leading Researcher Institute of Geology, Kola Science Centre of RAS

14 Fersman St, Apatity 184209, Russia

e-mail: nik@geoksc.apatity.ru

ORCID: 0000-0003-0918-0995

\section{VICTOR P. KOVACH}

Candidate of Geology and Mineralogy, Senior Researcher Institute of Precambrian Geology and Geochronology of RAS 2 Makarova Emb, Saint Petersburg 199034, Russia e-mail: v.p.kovach@gmail.com ORCID: 0000-0002-2027-7256

\section{JULIA V. PLOTKINA}

Candidate of Geology and Mineralogy, Senior Researcher Institute of Precambrian Geology and Geochronology of RAS 2 Makarova Emb, Saint Petersburg 199034, Russia e-mail: jplotkina@yandex.ru ORCID: 0000-0001-6171-6051

\section{РОМАН ОЛЕГОВИЧ ОВЧИННИКОВ}

M.H.C.

Институт геологии и природопользования ДВО РАН 675000, г. Благовещенск, пер. Рёлочный, 1, Россия

\section{АНДРЕЙ АНАТОЛЬЕВИЧ СОРОКИН}

докт. геол.-мин. наук, чл.-корр. РАН, зав. лабораторией, директор

Институт геологии и природопользования ДВО РАН 675000, г. Благовещенск, пер. Рёлочный, 1, Россия

\section{НИКОЛАЙ МИХАЙЛОВИЧ КУДРЯШОВ}

канд. геол.-мин. наук, в.н.с. Геологический институт КНЦ РАН 184209, г. Апатиты, ул. Ферсмана 14, Россия

\section{ВИКТОР ПЕТРОВИЧ КОВАЧ}

канд. геол.-мин. наук, с.н.с.

Институт геологии и геохронологии докембрия РАН 199034, Санкт-Петербург, наб. Макарова, 2, Россия

\section{ЮЛИЯ ВЛАДИМИРОВНА ПЛОТКИНА}

канд. геол.-мин. наук, с.н.с.

Институт геологии и геохронологии докембрия РАН 199034, Санкт-Петербург, наб. Макарова 2, Россия 


\section{TATIANA M. SKOVITINA}

Candidate of Geology and Mineralogy, Senior Researcher Institute of the Earth's Crust, SB RAS

128 Lermontov St, Irkutsk 664033, Russia

e-mail: skovit@crust.irk.ru

ORCID: 0000-0003-0824-0220

\section{ТАТЬЯНА МИХАЙЛОВНА СКОВИТИНА}

канд. геол.-мин. наук, с.н.с.

Институт земной коры СО РАН

664033 , г. Иркутск, ул. Лермонтова 128, Россия 